ACCEPTED FOR PUBLICATION

AUTHORS SUBMISSION VERSION

Please cite the BRI version of this paper using the

following DOI: 10.1080/09613218.2017.1399719

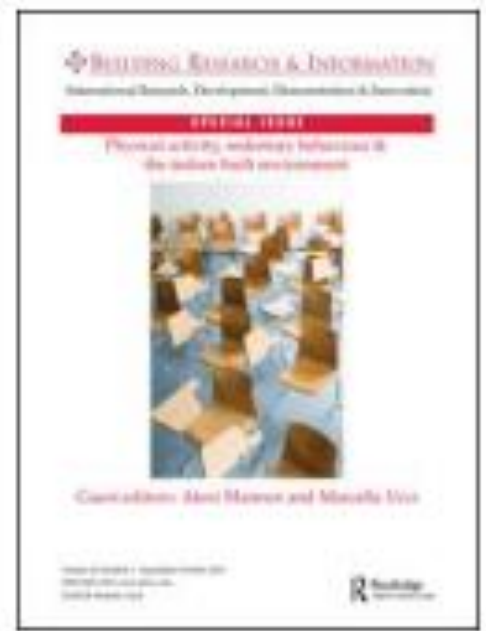

Developing English domestic occupancy profiles

Author(s): Victoria Aragon, Stephanie Gauthier, Peter Warren, Patrick James, Ben Anderson

Source: Building Research \& Information.

DOI: 10.1080/09613218.2017.1399719, Available online: 28 November 2017 


\section{Developing English domestic occupancy profiles}

Victoria Aragon ${ }^{1,}{ }^{*}$, Stephanie Gauthier ${ }^{1}$, Peter Warren ${ }^{2}$, Patrick A.B. James ${ }^{1}$, Ben. Anderson ${ }^{1}$ ${ }^{1}$ University of Southampton, Faculty of Engineering \& the Environment, Highfield Campus, Southampton, SO17 1BJ, United Kingdom

${ }^{2}$ Department for Business, Energy \& Industrial Strategy, 1 Victoria Street, London, SW1H OET, United Kingdom

${ }^{*}$ E-mail: V.Aragon@soton.ac.uk

\section{ABSTRACT}

Occupancy patterns are necessary to estimate energy demand and evaluate thermal comfort in households. Because of this, many European countries are developing representative domestic schedules to replace outdated criteria. This paper evaluates the state of knowledge of UK domestic occupancy patterns and develops new domestic occupancy profiles for England. The presented research (1) characterizes methods for collecting occupancy data and inferring patterns; (2) identifies and assesses the quality of categories of occupancy patterns used in building simulation; and (3) develops updated occupancy profiles. A systematic scoping review identified social and monitoring surveys as the most deployed data-collection methods. A systematic literature review also established that the occupancy categories most frequently used in UK building simulation are (a) a family with dependent children where the parents work full time; and (b) a retired elderly couple who spend most of their time indoors. The interview sample from the English Housing Survey 2014-15 was used to map household typologies. Results show that categories (a) and (b) combined amount to only 19\% of England's households, which suggest models are over-reliant on these groups. Considering this result, the paper develops occupancy patterns for England derived from 2015 UK Time Use Survey diaries for each household typology previously identified.

\section{KEYWORDS}

demographics; households; modelling; monitoring; occupancy patterns; occupant behaviour; occupants; social survey; time use 


\section{Introduction}

Occupancy can refer to when a person is at home as well as in which part of the house, and whether the occupant is active or inactive. Occupancy patterns reflect behaviour that is most probable during a certain period of time, and are determining factor of energy consumption profiles (Marshall, Steinberger, Dupont, \& Foxon, 2016; Yohanis, Mondol, Wright, \& Norton, 2008). The main drivers of occupancy patterns are socio-demographic characteristics of occupants (Huebner, Hamilton, Chalabi, Shipworth, \& Oreszczyn, 2015).

The study of occupancy patterns finds application in building simulation as an input in bottom-up models for estimating energy demand, evaluating thermal comfort and assessing compliance with respect to building regulations or other standards. Despite the relevance of this analysis, both in European and UK studies there is little agreement on how to group the population by their occupancy patterns (Hong, Taylor-Lange, D'Oca, Yan, \& Corgnati, 2016). In the absence of representative categories, outdated schedules are often used.

In the UK, where domestic energy demand is driven by heating and electricity with little to no cooling, the most used set of patterns is based on the annual energy demand calculation method, the Building Research Establishment's (BRE) Domestic Energy Model (BREDEM). This model presents a default occupancy schedule for a family with small children where the adults work full time during weekdays (Anderson et al., 2008). Several studies acknowledge that other household types should be evaluated and present additional scenarios (Gupta \& Gregg, 2013; Marshall et al., 2016; Mavrogianni et al., 2014; Porritt, Shao, Cropper, \& Goodier, 2010). Nevertheless, there is no agreement as to which or how many household categories should be considered and what are their occupancy schedules (University of Southampton (UoS), 2016).

A second application of occupancy patterns is in regional and national planning to identify factors that impact the management of electrical grids and thermal networks. Identifying household groups that have similar occupancy schedules and/or energy behaviour presents a major opportunity for policy-makers (Chaney, Hugh Owens, \& Peacock, 2016; Zhang, Siebers, \& Aickelin, 2012). The challenge is acquiring high-quality 
data; this is crucial for ensuring that models accurately reflect energy-consumption patterns.

Occupancy data can be obtained by different methods depending on their use and the availability of resources. Previous studies (Gaetani, Hoes, \& Hensen, 2016; Jia, Srinivasan, \& Raheem, 2017; Zhang \& Jia, 2016) have reviewed methodologies for collecting occupancy information, showing that patterns can be inferred from monitoring occupancy on site or carrying out social surveys. Monitoring may employ devices that capture occupants' presence directly such as infrared motion sensors or indirectly by measuring occupancy-related variables such as $\mathrm{CO} 2$ concentration or electricity consumption. Within social surveys, time-use surveys (TUSs) are used extensively across Europe.

This paper evaluates the current state of knowledge on occupancy patterns for the UK's domestic sector and develops representative occupancy patterns for England. A review of the literature on occupancy in buildings identifies gaps and analyses the quality of both existing data and the methodology used to obtain them. The characterization and inference of occupancy patterns is based on the findings from the literature review.

The paper is structured as follows. The next section reviews occupancy categories and data-collection, processing and analysis methods. The third section, household typologies are identified from the UK household sample from the 2014-15 English Housing Survey dataset (Department for Communities and Local Government (DCLG), 2017). In the final section, English domestic occupancy profiles are inferred through a statistical analysis of UK 2014-15 time-use diaries (Gershuny \& Sullivan, 2017). 


\section{Methods}

\subsection{Systematic literature review}

The first part of this study consists of a systematic review of the existing literature following the technique implemented by the UoS (2016) (Figure 1 shows the steps of the analysis). First, the boundaries of the review were defined. Second, search engines, databases and keywords were identified. Table 1 summarizes the research parameters. Relevant literature was selected, and after eliminating repeated studies and evaluating abstracts, a body of literature for full assessment was obtained. Studies were classified according to their focus (e.g. data-collection, modelling and occupancy categories), type of environment (domestic or commercial), and country of origin. A quality assessment was carried out evaluating clarity, justification, methodology, the track record of the authors and level of review.

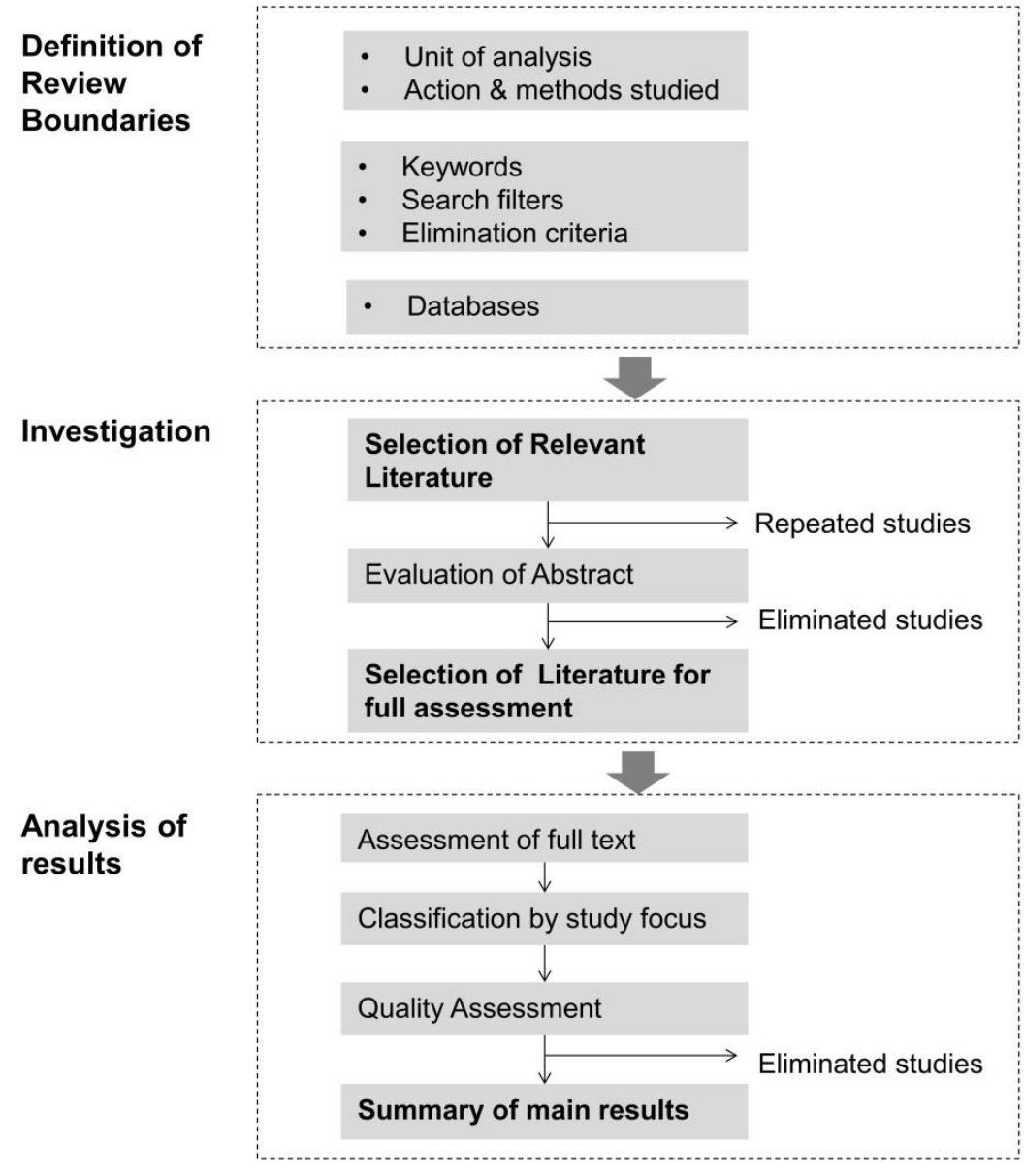

Figure 1. Scoping review systematic technique. 
Table 1. Parameters of the literature review.

Unit of analysis: Domestic dwellings

\begin{tabular}{|c|c|}
\hline Action studied: & Occupancy \\
\hline Methods studied: & Surveying, modelling \\
\hline Keywords: & 'domestic', 'occupancy', 'patterns', 'profiles', 'behaviour' \\
\hline $\begin{array}{l}\text { Search engines and } \\
\text { databases: }\end{array}$ & $\begin{array}{l}\text {-Web of Sciences, Scopus, Google Scholar, OpenGrey -eScholarship from the } \\
\text { University of California, ICE, IEEE, Chartered Institution of Building } \\
\text { Services Engineers (CIBSE) The Royal Institute of } \\
\text { British Architects (RIBA), Building Research } \\
\text { Establishment (BRE) and BSRIA databases } \\
\text { - UK government website }\end{array}$ \\
\hline
\end{tabular}

Publication year: $\quad$ From 1980 onwards

Country of origin: The UK as the primary focus for a review of patterns

The UK and international for a review of data- collection and analysis methodologies

\subsection{Analysis of an English Housing Survey household sample}

The second part of this paper consists of an analysis of household interviews from the English Housing Survey 2014-15. These are the answers to questionnaires from 13,174 households on the socio-economic characteristics of occupants, family composition and tenure. The sample of the English Housing Survey 2014-15 was designed to be representative across tenure, following a two-step systematic random design described in the English Housing Survey Technical Report (DCLG, 2015a, ch. 1).

The first stage of the sample selection consisted of dividing England's map into geographical clusters with an equal number of addresses. All clusters were stratified by census estimates on tenure and work status. They were then randomly allocated to different interview years, each year covering half of England. The second stage involved a stratification of all addresses in the clusters assigned to the 2014-15 interview year, after which an initial sample of 40,000 addresses was randomly selected. All addresses were obtained from the Royal Mail's Small User Postcode Address File. The 40,000 addresses were then subsampled to represent accurately less prevalent areas such as social rented, 
and were passed to interviewers. After evaluating eligibility and contacting residents, interviews were carried out in 13,174 houses.

Weighting factors were assigned to each household to correct for the subsampling process (where less-prevalent tenure groups are over-sampled) and differential nonresponse. This sampling method results a representative sample of English households. However, it is a partially clustered survey when using data from one year only (with an estimated maximum design factor of 1.08). This issue can be resolved by using two years of data. The analysis in this paper identified household typologies from the 2014-15 data set only. The sample was segmented to obtain groups of distinct household composition and the work status of occupants. Figure 2 shows each step of the segmentation resulting in 33 groups.

Household composition was defined combining two variables, hhcompx and hhtype11, which give information on the relationship between occupants, age and type of children. Children are classified by the Office for National Statistics (ONS) into dependent and non- dependent (ONS, 2016a). Dependent children are those living with their parents (1) who are under 16 years of age; or (2) those aged 16-18 years who are in full-time education. Non-dependent children (also known as adult children) are those who live with their parents aged 16-18 years and not in full-time education; aged 19 years or older; or (3) living with a spouse or children in the house. Work status was evaluated for all occupants aged 16 years or over. The number of people working full time (variable SFT) was compared against the total number of adults in the household. The number of adults was calculated by subtracting the number of dependent children (ndepchild) from household size (hhsizex). Finally, weighting factors (aggfh14) were applied so that national estimates are representative. 


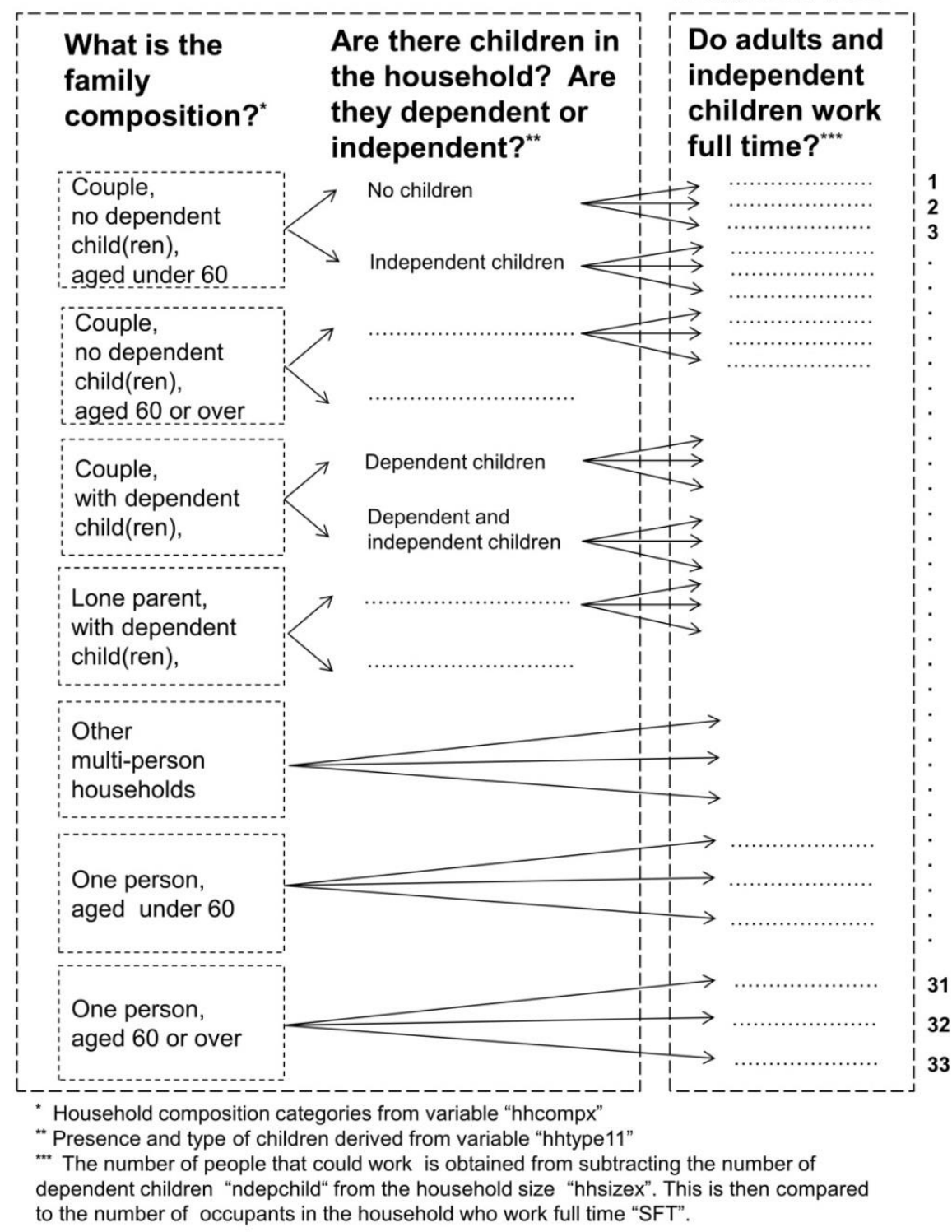

Figure 2. Segmentation of an English Housing Survey household sample.

\subsection{Analysis of UK Time Use Survey (TUS) diaries}

The final part of this paper consists of the analysis of UK 2014-15 TUS diaries from 1,407 English households to develop a set of occupancy patterns that can be applied in building simulation. The TUS gives an overview on how people spend their time daily. It comprises household and individual interviews, and self-completion diaries.

For the 2014-15 survey, houses were selected through a two-step process (Morris, Humphrey, Alvarez, \& Lima, 2016). The first step was obtaining a random sample of primary 
sampling units (PSUs). The probability of selection was proportional to the number of postal addresses in each PSU. All addresses in each unit were stratified according to region, population density and socio-economic grouping. The second step was selecting a random sample of postal addresses within PSUs.

The addresses were randomly allocated to different yearly quarters to cover all months evenly, and each address was randomly allocated two diary days, one weekday and one weekend. Household heads answered the house-level questionnaire. All individuals aged 8 years or over were eligible for interviews and diaries (those aged 8-13 years were provided with a simpler version). Weights were assigned, similarly to the English Housing Survey, to cover non-response bias and non-covered areas as well as differential selection probabilities.

The data sets used from the UK TUS 2014-15 data set were: individual diaries (uktus15_diary_wide), individual interviews (uktus15_individual) and household interviews (uktus15_household). Households with incomplete diaries or interviews were eliminated; only productive interviews were used.

The first stage of the analysis was to assess household composition and individual work status to match the 33 groups found in the English Housing Survey sample. Regarding composition, the UK TUS provides eight household categories (variable dhhtype) different from those in the English Housing Survey. This required re-categorizing households by analysing individual interviews and the relationship between occupants. Work status was evaluated in the same way as in the English Housing Survey.

Furthermore, three occupancy states ('at home and sleeping', 'at home and not sleeping' and 'away from home') were defined based on the review of occupancy models in the literature. Individual diaries were analysed and each time slot was assigned a state based on the respondent's declared activity and location. The number of people in each state was added per household for each time slot and compared against the number of respondents at each time slot. This resulted in state probabilities at the household level. Finally, state probabilities were averaged per household group and day of the week considering weighting factors. The result is a set of time series for each group and state by day of the week (Figure 3). 
UK TUS 2014/2015

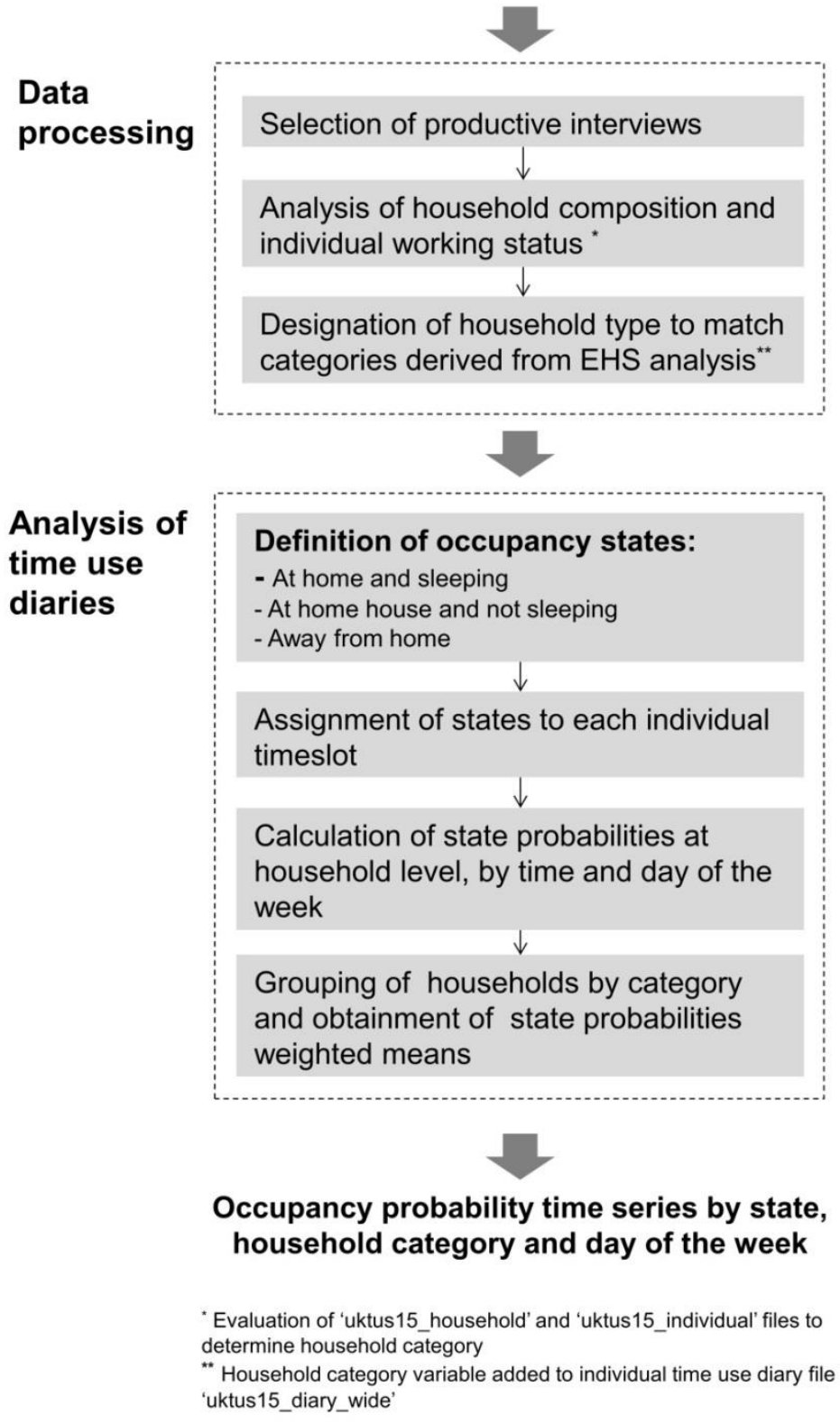

Figure 3. Analysis of UK Time Use Survey 2014-15 diaries. 


\section{Literature scoping review}

\subsection{Review of methods used for collecting data on occupancy}

The validity of occupancy patterns depends on the methods applied to obtain them; hence, data collection is a key issue to ensure an accurate representation of reality. This section reviews research from international sources focused on both domestic and commercial studies. Within the existing literature two data-collection methods stand out: social surveys and monitoring surveys. The following sections will review the main data-collection methods in detail.

\section{Social surveys}

Social surveys in the context of this paper refer to methods used to gather subjective information from participants. Often the researcher is present during the data collection: his/her role ranges from active interviewer to passive observer. Each method presents advantages and limitations, which will need to be carefully weighted-up for a specific project. Table 2 reviews the main types of social surveys. Each social survey method will have limitations mainly linked to 'participant bias', whereby participants may not want to reveal some information or be perceived in a certain way. However, social surveys capture socio-demographic information and, more importantly, reported information - when, how and why people occupy their homes the way they do. These survey tools enable researchers to engage with what is of importance to the occupants and the rationales/motivations for their occupancy patterns. Teasing out these rationales is critical for policy if one needs to adapt to or change current occupancy patterns.

Within social surveys, diaries are often applied in the form of TUSs for obtaining data representative of a large population (Chau et al., 2012) and are extensively used to generate occupancy patterns. TUSs consist of diaries completed by residents of private households over two days (consecutive or not) with entries every 10 minutes (Gershuny, 2011). If European guidelines are followed, diaries from different countries may be compared (EUROSTAT, 2004). One drawback of applying this methodology is that there is no long-term 
year.

Table 2. Social surveys.

\begin{tabular}{|c|c|c|c|c|}
\hline Method & Format & Application & Constraints & Key references \\
\hline $\begin{array}{l}\text { Question- } \\
\text { naires }\end{array}$ & $\begin{array}{l}\text { Structured survey } \\
\text { administered by the } \\
\text { researcher during a } \\
\text { meeting, over the } \\
\text { phone, by post or } \\
\text { email. }\end{array}$ & $\begin{array}{l}\text { Used in casual } \\
\text { research to explore } \\
\text { the cause and effect } \\
\text { relationship between } \\
\text { variables. The format } \\
\text { allows for ease of } \\
\text { replicability, being } \\
\text { applicable to large } \\
\text { populations. }\end{array}$ & $\begin{array}{l}\text { Lack of opportunity } \\
\text { for follow-up } \\
\text { questions. } \\
\text { Emails may introduce } \\
\text { sub-sampling effects. }\end{array}$ & $\begin{array}{l}\text { Guerra-Santin } \\
\text { and Itard } \\
(2010)\end{array}$ \\
\hline Interviews & $\begin{array}{l}\text { Private meeting, } \\
\text { where one } \\
\text { participant is invited } \\
\text { to discuss a topic } \\
\text { with the researcher. } \\
\text { Using a guide with } \\
\text { questions or } \\
\text { prompts, interviews } \\
\text { may be structured } \\
\text { to unstructured. }\end{array}$ & $\begin{array}{l}\text { Exploratory and } \\
\text { descriptive research to } \\
\text { define better } \\
\text { occupancy and/or the } \\
\text { rationale behind them. } \\
\text { Allows discussing and } \\
\text { explaining } \\
\text { questions/topics if } \\
\text { necessary. }\end{array}$ & $\begin{array}{l}\text { Possible bias by the } \\
\text { 'interviewer effect'. } \\
\text { Difficult to replicate, } \\
\text { each interview will be } \\
\text { different. }\end{array}$ & $\begin{array}{l}\text { Gram-Hansen } \\
\text { (2010) }\end{array}$ \\
\hline $\begin{array}{l}\text { Focus } \\
\text { groups }\end{array}$ & $\begin{array}{l}\text { Group meeting } \\
\text { where participants } \\
\text { are invited to } \\
\text { discuss a topic under } \\
\text { the direction of a } \\
\text { moderator. }\end{array}$ & $\begin{array}{l}\text { Exploratory research } \\
\text { to reveal new insights, } \\
\text { e.g. when do people } \\
\text { occupy their home. }\end{array}$ & $\begin{array}{l}\text { Possible bias due to } \\
\text { 'group effect' and } \\
\text { 'moderator effect', } \\
\text { where participants } \\
\text { may aim to please the } \\
\text { group or the } \\
\text { moderator and alter } \\
\text { their response }\end{array}$ & $\begin{array}{l}\text { McMichael } \\
\text { (2011) }\end{array}$ \\
\hline Diaries & $\begin{array}{l}\text { Self-completed } \\
\text { questions at specific } \\
\text { times. Can be } \\
\text { automated to trigger } \\
\text { an entry from } \\
\text { participants. }\end{array}$ & $\begin{array}{l}\text { Time use analysis, } \\
\text { evaluation of an } \\
\text { individual's behaviour. } \\
\text { Comparable and highly } \\
\text { replicable. }\end{array}$ & $\begin{array}{l}\text { Requires commitment } \\
\text { from participants. } \\
\text { Answers may vary } \\
\text { based on the time of } \\
\text { the day when the } \\
\text { diary is filled. The } \\
\text { completion of the } \\
\text { diary may interfere } \\
\text { with the activities. }\end{array}$ & $\begin{array}{l}\text { Chau et al. } \\
\text { (2012) }\end{array}$ \\
\hline $\begin{array}{l}\text { Observa- } \\
\text { tions }\end{array}$ & $\begin{array}{l}\text { The researcher } \\
\text { observes } \\
\text { participants and } \\
\text { takes records. The } \\
\text { researcher may join } \\
\text { the household or } \\
\text { observe passively, } \\
\text { through visual or } \\
\text { audio recording. }\end{array}$ & $\begin{array}{l}\text { Capturing actual } \\
\text { behaviours, in } \\
\text { particular their } \\
\text { duration, frequency } \\
\text { and sequencing. }\end{array}$ & $\begin{array}{l}\text { Possible observer } \\
\text { bias', also referred to } \\
\text { as the 'Hawthorne } \\
\text { effect, where } \\
\text { participants may } \\
\text { behave differently } \\
\text { when being observed. } \\
\text { Subjective to the } \\
\text { researcher and } \\
\text { his/her observations. }\end{array}$ & $\begin{array}{l}\text { Gauthier and } \\
\text { Shipworth } \\
\text { (2015) }\end{array}$ \\
\hline
\end{tabular}




\section{Monitoring surveys}

Monitoring surveys range from very simple technologies such as self-contained data loggers to advanced networks, allowing for flexibility in studies' scale and settings. As stand-alone tools or in conjunction with social surveys, researchers may use stationary and/or wearable loggers. Stationary loggers refer to sensors bound to the physical environment, whereas wearable loggers are carried by the participants (Spataru \& Gauthier, 2014). Stationary loggers are used more often because of being less intrusive. Tables 3 and 4 highlight different types of stationary and wearable sensors and their main characteristics.

Many studies have applied mixed-method data-collection approaches where social surveys and sensors have been deployed concurrently. Sensors' data logging may take place locally within each device or via a network and associate gateway to a centralized data depository (Spataru \& Gauthier, 2014). In the context of the internet of things, networks of sensors incorporate built-in processing and gateways, which enables automated alerts and surveys to be sent to participants when a change in log occurs (Al-Fuqaha, Guizani, Mohammadi, Aledhari, \& Ayyash, 2015; Perera, Zaslavsky, Christen, \& Georgakopoulos, 2014). This approach allows one to single out specific occupancy patterns and to gather the motivations for those in real time.

The choice of methods will generally be constrained by a study's budget and lifetime, thus there is a real advantage in using pre-installed technologies such as building management and security systems. Because of this, smart meters are an excellent method for large- scale monitoring, relying on already installed technology and being non-intrusive. Furthermore, it is important to consider that the appropriateness of each monitoring device may differ by country. For example, air-pressure sensors may not be suitable in warm climates where windows may be left open. Also, attention should be drawn to the differences between collecting data from domestic and commercial buildings. Usually commercial spaces are communal areas shaped by social norms, rules and use of spaces, which translates into zones with distinct and regular occupancy patterns (Sailer, Pomeroy, \& Haslem, 2015). In contrast, in the home the use of space may be driven by the concept of privacy (Alitajer \& Molavi Nojoumi, 2016; Prevost, Baetz, Razavi, \& El- Dakhakhni, 2015). 
Table 3. Stationary loggers.

\begin{tabular}{lll} 
Method & Operation principle & Application \\
\hline Energy & Non-intrusive & Applicable to \\
meter & monitoring. & residential and non- \\
& Inference of & residential \\
& participants' & environments. This \\
presence from & data collection \\
& electricity & method should \\
consumption. & become mainstream \\
& & in homes with the \\
& roll-out smart meters.
\end{tabular}

Constraints

A high resolution of energy monitoring is necessary to infer occupant behaviour patterns.

\begin{tabular}{ll}
\hline Passive & Sensors are \\
infrared & sensitive to heat \\
sensors & waves from a warm \\
(PIR) & object (e.g. human \\
sensors & body). They identify \\
& occupancy by \\
& detecting motion \\
& and giving out a \\
& binary time series of \\
& movement records.
\end{tabular}

\begin{tabular}{|c|c|c|}
\hline $\begin{array}{l}\mathrm{CO}_{2} \\
\text { sensors }\end{array}$ & $\begin{array}{l}\text { Sensors capture } \\
\text { changes in the } \mathrm{CO}_{2} \\
\text { concentration level } \\
\text { associated with } \\
\text { participants' }\end{array}$ & $\begin{array}{l}\text { Affordable and } \\
\text { relatively easy to } \\
\text { deploy. Most data } \\
\text { loggers will need } \\
\text { mains power. }\end{array}$ \\
\hline
\end{tabular}

$\begin{array}{ll}\begin{array}{l}\text { Applicable to } \\ \text { residential and non- } \\ \text { residential }\end{array} & \begin{array}{l}\text { Sensors do not } \\ \text { differentiate between } \\ \text { environments. }\end{array} \\ \begin{array}{l}\text { Available, affordable } \\ \text { and easy to install. } \\ \text { multiple occupants. If is } \\ \text { Simple data analysis. }\end{array} & \begin{array}{l}\text { moving slowly or is still } \\ \text { then a false negative } \\ \text { reading occurs. Pets in } \\ \text { the household may } \\ \text { trigger the sensor, } \\ \text { giving false positive } \\ \text { readings }\end{array}\end{array}$

Loggers must be

plugged into mains

electric power. The

ventilation rate will

affect the data, which

may lead to a

misinterpretation of the

results.
Key References

Akbar, Nati, Carrez, and

Moessner (2015), Albert and

Rajagopal (2013), Chaney et

al. (2016), Anderson, Lin,

Newing, Bahaj, and James

(2017), Kleiminger, Beckel,

Staake, and Santini (2013),

Chen, Barker, Subbaswamy,

Irwin, and Shenoy (2013),

Zhao, Lasternas, Lam, Yun, and Loftness (2014)

Spataru and Gauthier (2014)

Agarwal et al. (2010),

Kleiminger et al. (2013),

Mahmoud, Lotfi, and

Langensiepen (2010)

\begin{tabular}{|c|c|c|c|c|}
\hline $\begin{array}{l}\text { Acoustic } \\
\text { sensors }\end{array}$ & $\begin{array}{l}\text { Change in sounds } \\
\text { levels may be } \\
\text { related to people's } \\
\text { activities and } \\
\text { therefore presence } \\
\text { in buildings. }\end{array}$ & $\begin{array}{l}\text { Affordable and easy } \\
\text { to deploy. Data } \\
\text { storage capacity } \\
\text { might be an issue for } \\
\text { a monitoring period } \\
\text { of more than one } \\
\text { week as the sampling } \\
\text { rate needs to be high. }\end{array}$ & $\begin{array}{l}\text { Adjacent properties and } \\
\text { external noise will affect } \\
\text { the data. }\end{array}$ & $\begin{array}{l}\text { Bian, Abowd, and Rehg } \\
\text { (2005) }\end{array}$ \\
\hline $\begin{array}{l}\text { Air } \\
\text { pressure } \\
\text { sensors }\end{array}$ & $\begin{array}{l}\text { While monitoring } \\
\text { the ventilation } \\
\text { systems, a change in } \\
\text { internal air pressure } \\
\text { from opening a } \\
\text { door or a window } \\
\text { may also be used to } \\
\text { infer occupancy } \\
\text { patterns. }\end{array}$ & $\begin{array}{l}\text { Only applicable in } \\
\text { dwelling with } \\
\text { mechanical } \\
\text { ventilation systems. } \\
\text { The single sensing } \\
\text { unit is linked to an air } \\
\text { filter with data } \\
\text { processing } \\
\text { capabilities. }\end{array}$ & $\begin{array}{l}\text { In dwellings with high } \\
\text { air tightness, the } \\
\text { external air pressure } \\
\text { will affect the data. }\end{array}$ & $\begin{array}{l}\text { Patel, Reynolds, and Abowd } \\
\text { (2008) }\end{array}$ \\
\hline $\begin{array}{l}\text { Device- } \\
\text { free } \\
\text { Localisati } \\
\text { on (DfL) }\end{array}$ & $\begin{array}{l}\text { This sensor } \\
\text { estimates the } \\
\text { absorption of radio } \\
\text { signals by the } \\
\text { occupants' body to } \\
\text { derive occupancy } \\
\text { patterns. }\end{array}$ & $\begin{array}{l}\text { Emerging technique. } \\
\text { Data processing may } \\
\text { need to be dwelling } \\
\text { specific distinguish } \\
\text { between activity } \\
\text { types. }\end{array}$ & $\begin{array}{l}\text { Careful considerations } \\
\text { should be given to the } \\
\text { location of the sensors } \\
\text { as a clear line of sight of } \\
\text { the signal should be } \\
\text { maintained, } \\
\text { furthermore the precise } \\
\text { number of people } \\
\text { cannot be determined }\end{array}$ & $\begin{array}{l}\text { Naghiyev, Gillott, and Wilson } \\
\text { (2014) }\end{array}$ \\
\hline
\end{tabular}


Table 4. Wearable loggers.

\begin{tabular}{|c|c|c|c|c|}
\hline Method & Operation principle & Application & Constraints & Key References \\
\hline $\begin{array}{l}\text { Wearable } \\
\text { loggers } \\
\text { with } \\
\text { navigation } \\
\text { systems. }\end{array}$ & $\begin{array}{l}\text { Wearable loggers to } \\
\text { monitor occupancy } \\
\text { may apply geolocation } \\
\text { sensing including } \\
\text { Global Positioning } \\
\text { System (GPS) or } \\
\text { inertial navigation } \\
\text { (direction and speed } \\
\text { of movement) }\end{array}$ & $\begin{array}{l}\text { Occupants may } \\
\text { already have } \\
\text { these sensors } \\
\text { within their } \\
\text { wearable } \\
\text { devices. }\end{array}$ & $\begin{array}{l}\text { Battery life might be an } \\
\text { issue. Furthermore, } \\
\text { participants may alter } \\
\text { their behaviour as they } \\
\text { know they are being } \\
\text { monitored (Hawthorne } \\
\text { effect) and privacy } \\
\text { might be an issue. }\end{array}$ & $\begin{array}{l}\text { Rodriguez } \\
\text { and Shala } \\
\text { (2011) }\end{array}$ \\
\hline $\begin{array}{l}\text { Wearable } \\
\text { loggers } \\
\text { coupled } \\
\text { with } \\
\text { stationary } \\
\text { sensors }\end{array}$ & $\begin{array}{l}\text { Include Radio } \\
\text { Frequency } \\
\text { IDentification (RFID) } \\
\text { using tags and beacons } \\
\text { Bluetooth or ultrasound } \\
\text { systems using } \\
\text { tags/phone and } \\
\text { beacons and wireless } \\
\text { networks using phone } \\
\text { and beacons }\end{array}$ & $\begin{array}{l}\text { Short periods } \\
\text { of monitoring. }\end{array}$ & $\begin{array}{l}\text { These systems require } \\
\text { challenging set-up and } \\
\text { maintenance, and } \\
\text { furthermore } \\
\text { participants may } \\
\text { forget to wear their } \\
\text { beacons. The results } \\
\text { may also be influenced } \\
\text { by the Hawthorne } \\
\text { effect. }\end{array}$ & $\begin{array}{l}\text { Sturari et al. } \\
\text { (2016), Spataru, } \\
\text { Gillott, and Hall } \\
\text { (2010), Lazik and } \\
\text { Shih (2015), } \\
\text { Xiong and } \\
\text { Jamieson (2013) }\end{array}$ \\
\hline
\end{tabular}

In summary, the limitations of data-collection methods, such as ease of use and applicability, cost, resolution and type of output, use of the data and occupants' privacy, will determine which approach is more suitable. In the UK domestic context, the most accessible methods will be those with tools already deployed, including energy meters and geolocation sensing using smart phones. These however, will not reveal occupants' motivations; therefore, they should be combined with social surveys. Gathering occupants' motivations is critical to develop effective policies and to foster the development of tailored interventions (Dodier, Henze, Tiller, \& Guo, 2006; Howard \& Hoff, 2013).

\subsection{Review of occupancy modelling methods}

The type of data collected establishes the analysis methods to be applied, ranging from descriptive statistics, inferential statistics, modelling and data-mining. Modelling methods 
enable relationships to be drawn and general scenarios to be established. As reviewed by Gaetani et al. (2016), occupancy models include the following:

- schedules: include binary daily occupancy profiles based on socio-economic status

- deterministic models: assume causal relationships driving occupancy patterns

- non-probabilistic models: derived from monitoring data

- probabilistic/stochastic models: including logit, probit, Markov chain, Poisson and survival analysis

- agent-based models: focus on the interactions between occupants in a group and with the physical setting

- machine-learning models

As this paper focuses on the UK domestic context, this section reviews the data-analysis methods applied to the most accessible data-collection methods: TUSs, energy meters and geolocation sensing. These data- analysis methods are: Markov techniques applied to TUSs, and time-series analysis and machine-learning techniques applied to sensors' output. All these techniques aim to generate synthetic occupancy patterns.

\section{Probabilistic models with Markov chain processes applied to TUSs}

Markov chains are used to simulate random transitions. Given the stochastic nature of occupancy, they are extensively used for modelling. The main differences between models are the number of occupancy states defined, the order of the model and whether or not occupants are considered independent. Figure 4 shows the nodes scheme and transition probabilities matrix for a three- state model; each value represents the probability of changing from one state to the other.

The order of a Markov model refers to how many steps back of the chain are considered to calculate the probabilities of the next state. For example, given the states 'in the house' and 'out of the house' in a first order model, the probability of a person changing from being 'in' to being 'out' depends only on the fact that he or she is now 'in' and not on where he or she was previously. Additionally, occupant behaviour models are inhomogeneous. Homogeneity refers to whether the probabilities of changing states 
depend on time; when they do not then a Markov chain is homogeneous, and when they do it is in-homogeneous. Occupancy states are time dependent; the probability of a person changing his/her state from 'sleep' to 'awake', for example, will not be the same at 07:00 than at 02:00 hours.
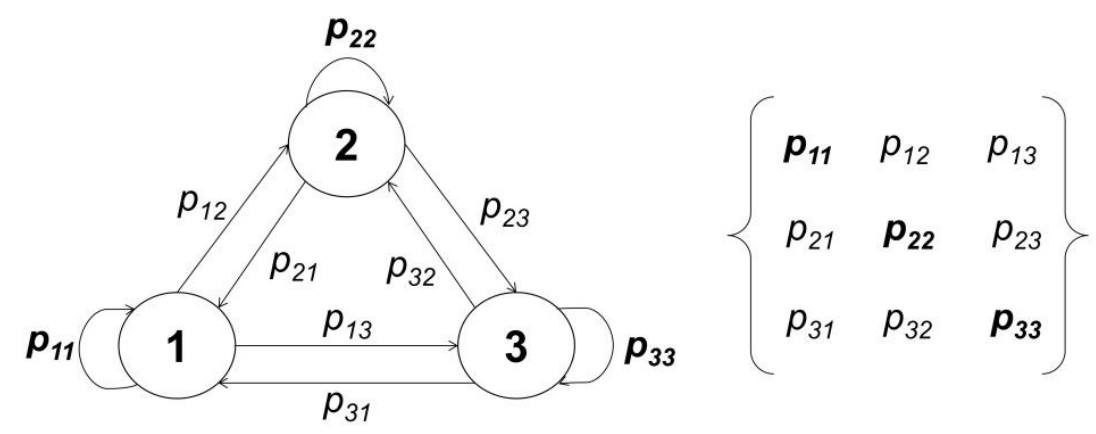

Figure 4. Three-state Markov chain state diagram and transition probability matrix.

The simplest models are first-order Markov chains. Richardson, Thomson, and Infield (2008) developed a model to generate synthetic occupancy based on UK time-use data that evaluates two states: 'in' or 'out' of the house. The model differentiates between weekdays and weekends and household size. Widen, Nilsson, and Wäckelgård (2009) designed a model for electrical demand where occupancy is modelled through a three- state Markov chain - 'in and inactive', 'in and active' and 'out' - from Swedish time-use data. Similarly to Richardson et al., Widen et al. differentiated between weekdays and weekends and building typology.

In both models, considering either household size or building typology is a way of accounting for correlations between occupancy patterns of people who live together. McKenna, Krawczynski, and Thomson (2015) evaluated the difference of modelling with or without correlation in multiple occupancy buildings showing that a correlated model reproduced accurate state probabilities, whereas an independent one presented significant errors.

Furthermore, Wilke, Haldi, Scartezzini, and Robinson (2013), Aerts, Minnen, Glorieux, Wouters, and Descamps (2014), and Flett and Kelly (2016) criticized first-order models on the basis that they do not predict duration accurately; they have lack of 'memory'. Firstly, Wilke et al. (2013) developed a model fitting Weibull distributions to the 
probabilities of states duration. Secondly, Aerts et al. (2014) proposed inferring the state duration probabilities from the time-use data (Belgian TUS) instead. Finally, Flett and Kelly (2016) performed a review of first-order Markov models and their limitations suggesting that both first- and higher-order models can capture active occupancy probabilities accurately, but higher-order models perform better for estimating duration of states. Flett and Kelly highlighted the importance of differentiating households when modelling, stating that the most determinant factors are household type, employment status and, later, age and gender.

\section{Time series analysis and machine learning models applied to monitoring data}

Methods used for analysing time series depend on the type of data (categorical or continuous) and whether they are from one or multiple sensors. As monitoring evolved from single to multiple sensors in a wireless network, time-series forecasting did, too, from traditional techniques such as autoregressive integrated moving average (ARIMA) models to machine-learning algorithms (Ahmed, Atiya, Gayar, \& El-Shishiny, 2010).

Wireless sensor networks such as used by Dong et al. (2010), Li, Zhang, and Duan (2008), and $\mathrm{Ai}$, Fan, and Gao (2014) present a simple solution to monitoring dynamic environments. However, the size and class of data call for flexible methods that can adapt to the type of problem analysed. Alsheikh, Lin, Niyato, and Tan (2014) evaluated the use of machine learning in wireless sensor networks stating that the main distinction between algorithms is the type of learning they require, whether it is supervised or unsupervised. Supervised methods such as decision tree, the k-nearest neighbours algorithm (KNN), support vector machine (SVM) and neural networks require training with data, whereas unsupervised methods such as k-means hierarchical clustering do not and are used to find clusters of similar characteristics. 


\section{Review of UK domestic occupancy patterns}

As the range of monitoring and data analysis methods allows for easier and more accurate occupancy recognition in specific scenarios, comparability of results calls for the use of standard occupancy parameters. For this reason, it is important to evaluate which categories of occupancy patterns are used in the UK literature, where they derive from and their application domain.

The most common occupancy schedule for the UK's domestic sector is that specified in BREDEM. It is used for UK Standard Assessment Procedure (SAP) calculations and compliance assessment, as well as in research and policy development for estimating energy demand and carbon emissions. The BREDEM model was designed for assessing heating demand in dwellings assuming that both active occupancy and heating patterns occur at the same time (Anderson et al., 2008). In the model, occupants are away during most of the day on weekdays and stay at home at the weekends. Dwellings are separated into two zones: zone 1 is the living area; and zone 2 represents the rest of the house. Figure 5 shows the schedules by zone and day of the week.

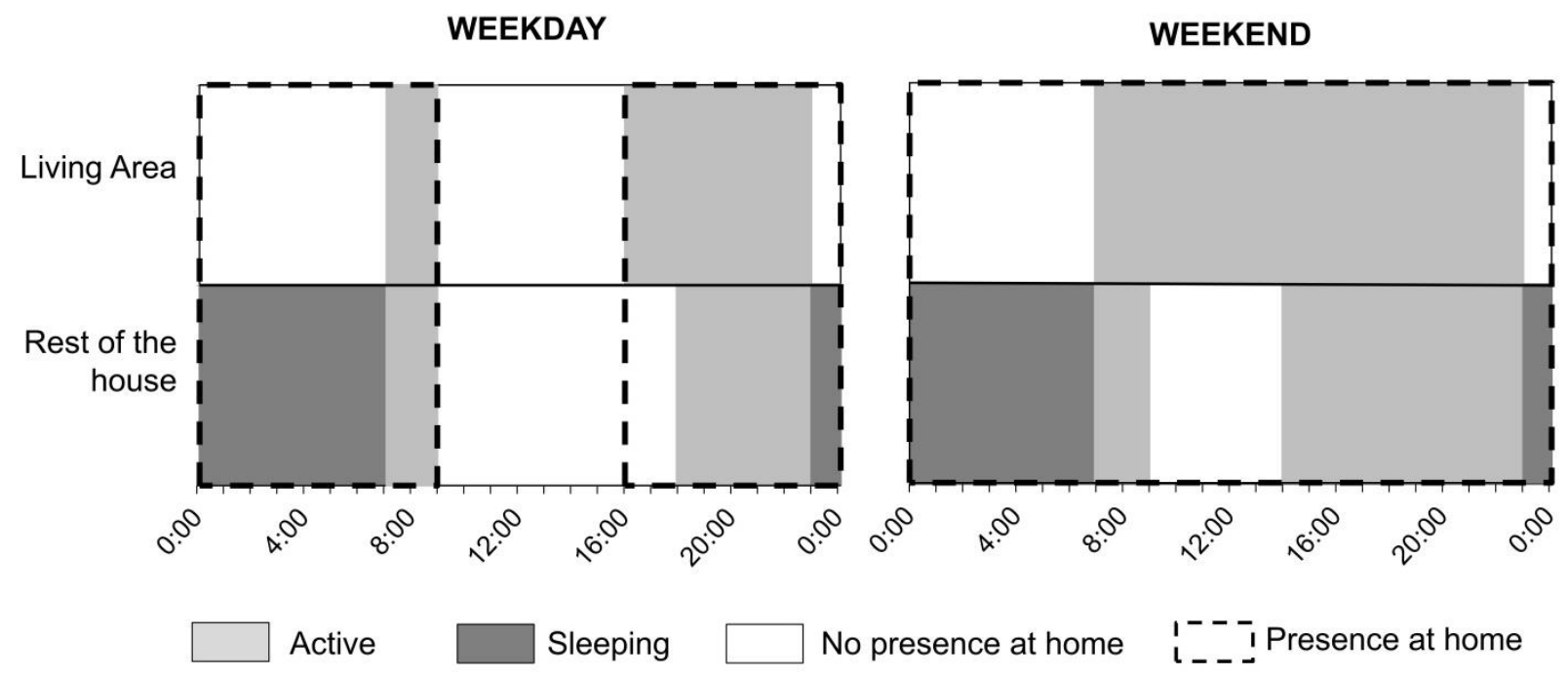

Figure 5. Building Research Establishment's (BRE) Domestic Energy Model (BREDEM) domestic active occupancy patterns for weekdays and weekends. The model is a methodology for estimating energy demand in buildings for the National Home Energy Rating (NHER) scheme used to generate energy certificates for domestic buildings. The default set of active occupancy patterns presented implies a complete absence of occupants during the day on weekdays and full presence during weekends. 
As BREDEM occupancy patterns were established for calculating heating demand, they represent the heating period alone; notwithstanding they are used for all seasons in modelling. Beyond the BREDEM model, other patterns may be used. Table 5 shows examples of household categories and their occupancy patterns used in UK studies by field of analysis: electrical load, heating demand and overheating risk.

Studies addressing overheating require occupancy to be separated into multiple zones, as thermal comfort guidelines for overheating (Nicol \& Spires, 2013) specify different compliance levels for bedrooms and living areas. Also, a distinction is made between two occupancy schedules: that of a family which is absent most of the day as presented by BREDEM, and one of an elderly couple with high daytime occupancy (Nicol \& Spires, 2013).

Amongst studies on electrical load demand, the focus is on when a person is active or inactive in the house rather than where they are within the household, presenting schedules of active occupancy. Identifying when people are at their homes and are active is the key for developing demand-response strategies. Chaney et al. (2016), for example, proposed targeting hours of the day when both occupancy and the variability of electrical load are high, meaning that there is potential for change.

Heating demand modelling studies apply schedules of active occupancy to identify when people are home and able to engage with their heating controls. For estimating both energy and heating demand additional household categories are used based on the working status of adults. Finally, a distinction of profiles between weekdays and weekends is made in some of the studies (Beizaee, Allinson, Lomas, Foda, \& Loveday, 2015; Cheng \& Steemers, 2011; Mavrogianni et al., 2014).

This paper argues that occupancy patterns need to be updated to represent adequately all sectors of the UK's population. So far there is not enough evidence within current research to generalize new occupancy profiles. 
Table 5. Domestic occupancy patterns in the UK literature.

\begin{tabular}{|c|c|c|c|}
\hline \multirow{2}{*}{\multicolumn{2}{|c|}{ Occupancy Categories }} & \multicolumn{2}{|l|}{ Occupancy Schedule } \\
\hline & & Weekday & Weekend \\
\hline \multicolumn{4}{|c|}{ Total Energy Demand: Heating and electricity } \\
\hline \multirow[t]{3}{*}{$\begin{array}{l}\text { Marshall et } \\
\text { al. (2015) }\end{array}$} & 1. Working family & $\begin{array}{l}\text { Active occupancy 07:00 to } 08: 30 \& 16: 00 \\
\text { to } 22: 30 \text { (All absent between } 08: 30 \text { and } \\
16: 00 \text { ) }\end{array}$ & NA \\
\hline & 2. Working couple & $\begin{array}{l}\text { Active occupancy 07:00 to 08:30 \& 18:00 } \\
\text { to } 23: 004 \text { days a week and 07:00 to } \\
\text { 08:30 \& 21:00 to 23:00 three times a } \\
\text { week }\end{array}$ & NA \\
\hline & 3. Daytime-present couple & $\begin{array}{l}\text { Active occupancy 07:00 to 23:00 all } \\
\text { week }\end{array}$ & NA \\
\hline \multirow[t]{5}{*}{$\begin{array}{l}\text { Beizaee et } \\
\text { al (2015) }\end{array}$} & $\begin{array}{l}\text { 1. Family: two working adults and } \\
\text { two school-aged children }\end{array}$ & Kitchen: $07: 30-08: 00$ \& 16:00 to 17:00 & $\begin{array}{l}\text { Kitchen: 09:00-09:30 \& 16:00 } \\
\text { to 17:00 }\end{array}$ \\
\hline & & Living Room: $18: 00$ to $22: 30$ & Living Room: $18: 00$ to $22: 30$ \\
\hline & & $\begin{array}{l}\text { Dining Room: 08:00-08:30 \& 17:00 to } \\
\text { 18:00 }\end{array}$ & $\begin{array}{l}\text { Dining Room: 09:30-10:00 \& } \\
\text { 17:00 to } 18: 00\end{array}$ \\
\hline & & $\begin{array}{l}\text { Bedroom 1: } 08: 30 \text { to } 09: 00,16: 00 \text { to } \\
17: 00,19: 00 \text { to } 08: 00\end{array}$ & $\begin{array}{l}\text { Bedroom 1: } 10: 00 \text { to } 10: 30 \text {, } \\
\text { 16:00 to } 17: 00,19: 00 \text { to } \\
\text { 09:30 }\end{array}$ \\
\hline & & Bedroom 2: $22: 30$ to 07:30 & Bedroom 2: 22:30 to 09:00 \\
\hline \multirow[t]{4}{*}{$\begin{array}{l}\text { Cheng et al } \\
\text { (2015) }\end{array}$} & $\begin{array}{l}\text { 1. One or more occupants work } \\
\text { full time }\end{array}$ & $\begin{array}{l}\text { Active occupancy 07:00 to 09:00 \& 18:00 } \\
\text { to } 23: 00\end{array}$ & $\begin{array}{l}\text { Active occupancy 09:00 to } \\
\text { 23:00 }\end{array}$ \\
\hline & $\begin{array}{l}\text { 2. One or more occupantswork } \\
\text { part time }\end{array}$ & $\begin{array}{l}\text { Active occupancy 07:00 to } 09: 00 \& 15: 00 \\
\text { to } 23: 00\end{array}$ & $\begin{array}{l}\text { Active occupancy 09:00 to } \\
\text { 23:00 }\end{array}$ \\
\hline & $\begin{array}{l}\text { 3. No occupant working, one or } \\
\text { more retired }\end{array}$ & Active occupancy 08:00 to $21: 00$ & $\begin{array}{l}\text { Active occupancy 09:00 to } \\
21: 00\end{array}$ \\
\hline & $\begin{array}{l}\text { 4. No occupant working and none } \\
\text { retired }\end{array}$ & Active occupancy 08:00 to $22: 00$ & $\begin{array}{l}\text { Active occupancy 09:00 to } \\
22: 00\end{array}$ \\
\hline \multirow{5}{*}{$\begin{array}{l}\text { Yao R, } \\
\text { Steemers K } \\
\text { (2005) }\end{array}$} & $\begin{array}{l}\text { 1.One or more working part-time } \\
\text { in the morning }\end{array}$ & Unoccupied from 09.00 to 13.00. & NA \\
\hline & $\begin{array}{l}\text { 2. One or more working part-time } \\
\text { in the afternoon }\end{array}$ & Unoccupied period from 13.00 to $18: 00$ & NA \\
\hline & 3. All working full time & Unoccupied period from 09.00 to 16.00 & NA \\
\hline & $\begin{array}{l}\text { 4. One or more working part-time } \\
2 / 3 \text { of the day }\end{array}$ & Unoccupied period from 09.00 to 16.00. & NA \\
\hline & 5. None working & Occupied all day & NA \\
\hline \multicolumn{4}{|c|}{ Overheating risk } \\
\hline \multirow{4}{*}{$\begin{array}{l}\text { Mavrogi- } \\
\text { anni } \\
\text { et al } \\
\text { (2013) }\end{array}$} & \multirow[t]{2}{*}{$\begin{array}{l}\text { 1. Family with two working adults and } \\
\text { between one and three children }\end{array}$} & $\begin{array}{l}\text { Living Room: Occupied 8:00-9:00 and } \\
\text { 19:00-22:00 }\end{array}$ & $\begin{array}{l}\text { Living Room: Occupied 10:00- } \\
\text { 12:00 and 17:00-22:00 }\end{array}$ \\
\hline & & Bedroom: Occupied 23:00-7:00 & $\begin{array}{l}\text { Bedroom: Occupied 23:00- } \\
\text { 9:00 }\end{array}$ \\
\hline & \multirow[t]{2}{*}{$\begin{array}{l}\text { 2. Elderly Couple of pensioners being } \\
\text { constantly indoors. }\end{array}$} & $\begin{array}{l}\text { Living Room: Occupied 9:00-19:00 and } \\
\text { 20:00-22:00 }\end{array}$ & \\
\hline & & Bedroom: Occupied 22:00 to 07:00 & \\
\hline \multirow{4}{*}{$\begin{array}{l}\text { Porrit et } \\
\text { al, } \\
(2010)\end{array}$} & \multirow[t]{2}{*}{ 1. Family } & Living Room: Occupied 17:00 to 23:00 & NA \\
\hline & & Main bedroom: Occupied 22:30 to 07:00 & NA \\
\hline & \multirow[t]{2}{*}{ 2. Elderly Couple } & Living Room: Occupied 08:00 to 21:30 & NA \\
\hline & & Main bedroom: Occupied 21:30 to 08:00 & NA \\
\hline \multirow{4}{*}{$\begin{array}{l}\text { Gupta et } \\
\text { al } \\
\text { (2013) }\end{array}$} & \multirow{4}{*}{$\begin{array}{l}\text { 1.Famil with two working adults and } \\
\text { two children in school }\end{array}$} & Bedroom 1: Occupied 23:00-07:00 & NA \\
\hline & & Bedroom 2: occupied 23:00-07:00 & NA \\
\hline & & Living Room: occupied 18:00-22:00 & NA \\
\hline & & Bedroom: occupied 23:00-06:00 & NA \\
\hline
\end{tabular}




\subsection{Representativeness of occupancy patterns}

From the analysis of literature two schedules arise as the most frequently used: (1) a family with two adults working full time and small children, as suggested by BREDEM; and (2) an elderly couple over 60 years of age who stay at home most of the day. To evaluate the representativeness of these categories it is necessary to review the socioeconomic characteristics of UK households. For this purpose, the data set of household interviews from the English Housing Survey 2014-15 (DCLG, 2017) was used to develop household typologies. The results of this analysis are shown in Figure 6.

As explained in the 'methods' section of this paper, two criteria were chosen for segmenting the household sample: household composition and employment status. This was based on literature findings by Flett and Kelly (2016) and Huebner et al. (2015). Based on this segmentation, 33 distinct groups were obtained. Within those, groups (1) and (2) were amongst the largest but amount to only $18.7 \%$ of the households (6.2\% BREDEM scenario and $12.6 \%$ couple with no children over 60 years who do not work full time). This means that most English household types are currently excluded from studies.

Regarding household composition, results uncovered multiple typologies of relevant size which are currently not included in most analysis. Couples with no children, under 60 years of age (group A in Figure 6) represent a total of 13.7\% of English households. Additionally, single-person households (groups J and K in Figure 6) amount to $27.4 \%$ and have shown the largest growth since the 1960s (ONS, 2016a). Another group to be considered are couples with non-dependent children. This group has also shown a continuous growth as the number of young adults who live with their parents keeps rising (ONS, 2016b).

Regarding working status, results show that in $44 \%$ of English households no adults are working full time, of which two-thirds are over 60 years of age. With the UK's population predicted ageing trend (Government Office for Science, 2016), this group will continue to grow. Furthermore, there are additional factors that are not considered in this or previous analysis. One is home working, which introduces flexibility into people's schedules, resulting 
in a greater spread in occupancy hours (Baker \& Rylatt, 2008). Secondly, it is assumed that working days are Monday to Friday and weekends are on Saturday and Sunday. However, service industries - hotels, restaurants, retail - and others like transport, agriculture and communication involve working on weekends, which translates into almost $50 \%$ of the UK's workforce working regularly on Saturdays and more than $30 \%$ on Sundays (Parent-Thirion, Macias, Hurley,\& Vermeylen, 2007).
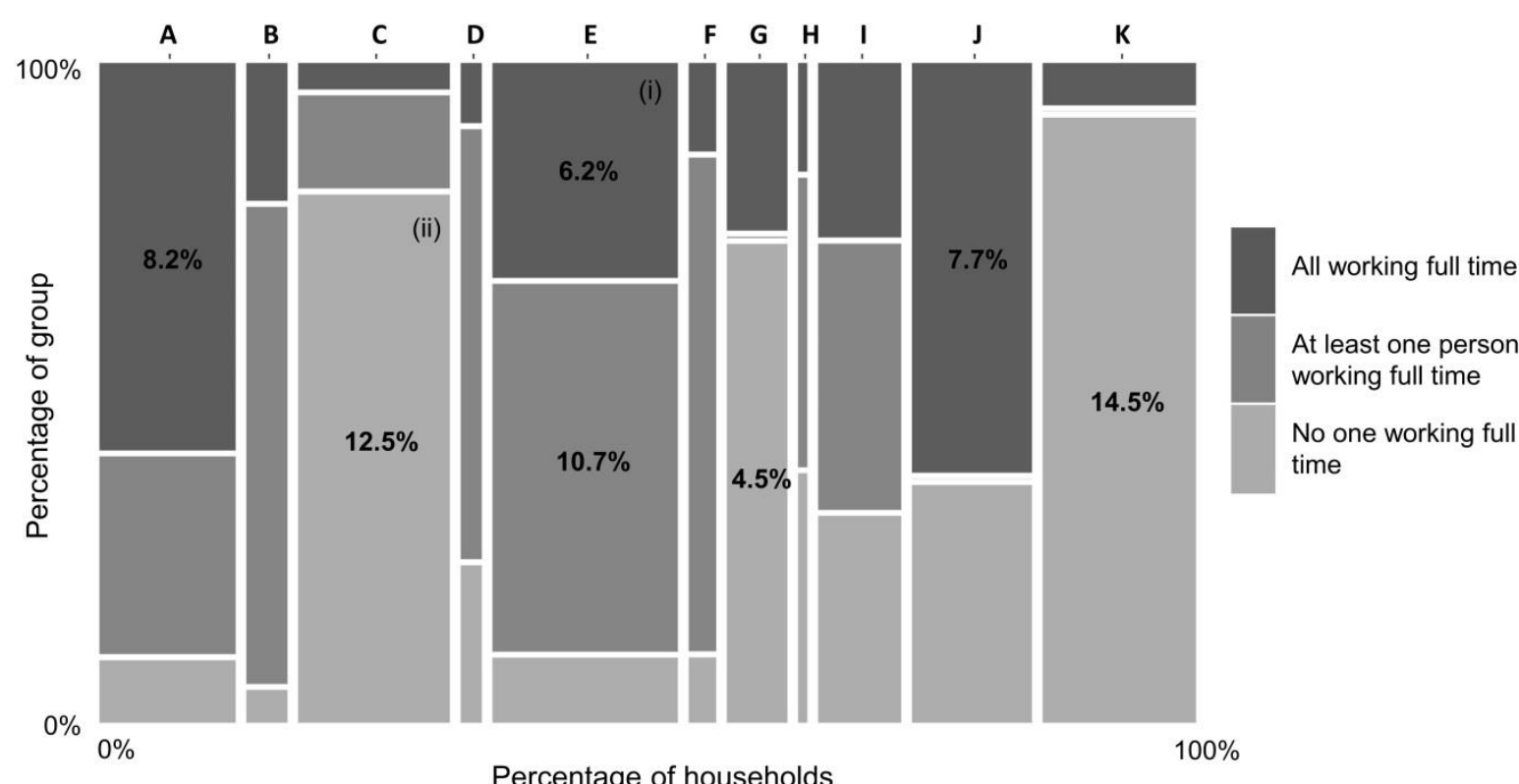

Percentage of households

\begin{tabular}{|c|c|c|c|c|c|}
\hline \multirow{2}{*}{\multicolumn{2}{|c|}{ Household composition group }} & \multirow[b]{2}{*}{ Total } & \multicolumn{3}{|c|}{ Household Work status } \\
\hline & & & $\begin{array}{l}\text { No one working full } \\
\text { time }\end{array}$ & $\begin{array}{l}\text { At least one person } \\
\text { working full time }\end{array}$ & $\begin{array}{l}\text { All working full } \\
\text { time }\end{array}$ \\
\hline A & Couple, under 60 years of age, no children & $13.8 \%$ & $1.3 \%$ & $4.2 \%$ & $8.2 \%$ \\
\hline B & $\begin{array}{l}\text { Couple, under } 60 \text { years of age, with non-dependent } \\
\text { child(ren) }\end{array}$ & $4.2 \%$ & $0.2 \%$ & $3.1 \%$ & $0.9 \%$ \\
\hline C & Couple, over 60 years of age, no children & $15.3 \%$ & $12.5 \%$ & $2.2 \%$ & $0.6 \%$ \\
\hline D & $\begin{array}{l}\text { Couple, over } 60 \text { years of age, with non-dependent } \\
\text { child(ren) }\end{array}$ & $2.1 \%$ & $0.5 \%$ & $1.4 \%$ & $0.2 \%$ \\
\hline E & Couple with dependent child(ren) & $18.8 \%$ & $1.9 \%$ & $10.7 \%$ & $6.2 \%$ \\
\hline $\mathbf{F}$ & Couple with dependent \& non-dependent child(ren) & $2.8 \%$ & $0.3 \%$ & $2.1 \%$ & $0.4 \%$ \\
\hline G & Lone parent with dependent child(ren) & $6.1 \%$ & $4.5 \%$ & - & $1.6 \%$ \\
\hline H & Lone parent dependent \& non-dependent child(ren) & $1.0 \%$ & $0.4 \%$ & $0.4 \%$ & $0.2 \%$ \\
\hline $\mathbf{I}$ & Multi-person household & $8.5 \%$ & $2.7 \%$ & $3.5 \%$ & $2.3 \%$ \\
\hline$J$ & One person, under 60 years of age & $12.1 \%$ & $4.4 \%$ & - & $7.7 \%$ \\
\hline & One person, over 60 years of age & $15.5 \%$ & $14.5 \%$ & - & $1 \%$ \\
\hline
\end{tabular}

Figure 6. English household categories by family composition and working status. 


\subsection{Occupancy patterns from the UK TUS}

Considering the results illustrated in Figure 6, the seven groups that each represent more than $4.5 \%$ of UK households were further analysed by using UK 2014-15 TUS data (Gershuny \& Sullivan, 2017) to develop new occupancy profiles.

The initial analysis of the data set involved assigning each household the corresponding group based on household composition and work status. The equivalences found between household composition categories in the English Housing Survey and the TUS are presented in Table 6. Additionally, given that these groups are derived from the English Housing Survey, only houses in England were considered (see Table 7 for sample sizes).

Table 6. Household composition equivalences between the UK Time Use Survey and the English Housing Survey.

Time Use Survey 2014-2015 English Housing Survey 2014-2015

Single person household / No children One person, over 60 One person, under 60

\begin{tabular}{ll}
\hline Couple with children $\leq 15$ & Couple with dependent child(ren) only \\
\hline Couple with no children $\leq 15$ & $\begin{array}{l}\text { Couple with, over 60, no child(ren) } \\
\text { Couple with, under 60, no child(ren) }\end{array}$ \\
\hline Single parent with children $\leq 15$ & Lone parent dependent child(ren) only \\
\hline Single parent with no children $\leq 15$ & $\begin{array}{l}\text { Lone parent dependent child(ren) only } \\
\text { Lone parent non-dependent child(ren) only } \\
\text { Lone parent dependent and non- } \\
\text { dependent child(ren) }\end{array}$ \\
\hline Unclassified - couples in complex households & n.a \\
\hline $\begin{array}{l}\text { Unclassified - single parents in complex } \\
\text { households }\end{array}$ & n.a \\
\hline Other unrelated & n.a
\end{tabular}

Three occupancy states were defined: 'at home and sleeping', 'at home and awake' and 'away from home' based on Widen et al.'s (2009) model. Widen et al. differentiate between people being active or inactive in the household, as activity can be an indication of energy usage (e.g. heating, appliances and lighting). This differentiation is particularly useful for simulations of energy demand. The state 'at home and sleeping' can be considered 
equivalent to 'at home and inactive' and can also be interpreted as occupancy in the bedroom. The state 'at home and not sleeping' can be compared with 'at home and active' and could also be interpreted as occupancy in the lounge.

Table 7. Household groups sample size.

\begin{tabular}{lc}
\hline Group & Number of households \\
\hline $\begin{array}{l}\text { One person, over 6o / Not working full } \\
\text { time }\end{array}$ & 276 \\
\hline $\begin{array}{l}\text { One person, under 60 / Working full } \\
\text { time }\end{array}$ & 245 \\
\hline $\begin{array}{l}\text { Couple with dependent child(ren) / All } \\
\text { working full time }\end{array}$ & 173 \\
\hline $\begin{array}{l}\text { Couple with dependent child(ren) / At } \\
\text { least one person working full time }\end{array}$ & 240 \\
\hline $\begin{array}{l}\text { Couple, over 60, no child(ren) / No one } \\
\text { working full time }\end{array}$ & 144 \\
\hline $\begin{array}{l}\text { Couple, under 60, no child(ren) / All } \\
\text { working full time }\end{array}$ & 232 \\
\hline $\begin{array}{l}\text { Lone parent with dependent child(ren) } \\
\text { / Not working full time }\end{array}$ & 97 \\
\hline Total & 1407 \\
\hline
\end{tabular}

The probabilities of each state along the day for every group were obtained for each day of the week. The resulting time series were tested for normality; all were non- normal. Therefore, Kruskal-Wallis tests were performed to determine if profiles are significantly different from each other (at the 0.05 significance level). Where results indicated a difference, post-hoc pairwise multiple comparisons were applied with Dunn's test. The analysis was divided in two: (1) analysis across days of the week for each group to evaluate if profiles should be differentiated between weekdays and weekends; and (2) analysis across groups for each day of the week to assess if daily profiles differ within groups.

The results of the Kruskal-Wallis tests from analysis (1) are presented in Table 8. The tests indicated that there were differences across days of the weeks within each group, particularly for active states 'at home and not sleeping' and 'away from home'. Additionally, post-hoc tests indicated differences across all days of the week. There was no clear pattern amongst weekdays; however, there was a significant difference between weekdays and weekend days. 
Appendix $A$ in the supplemental data online shows the results of the tests using Saturday as a control group. The number of weekdays that were significantly different from Saturdays was higher in those household groups where no one is working full time than in households where occupants work full time. These may be due to working pat- terns, as people working in the service sector may be working any day of the week, including weekends. More- over, only two groups, 'Lone parent with dependent child (ren)/not working full time' and 'Couple, over 60 years, no child(ren)/no one working full time', showed a significant difference between Saturdays and Sundays.

These results suggest that profiles may have to be differentiated across weekdays, but the findings are not conclusive enough to define how to group weekdays and weekends. For this reason, and as a direct comparison against BREDEM patterns, all weekdays were grouped together; Saturday and Sunday were analysed separately. The results of the Kruskal-Wallis test of analysis (2) are presented in Table 9. When comparing for each day of the week across states and groups, results showed that profiles of inactivity or 'at home and sleeping' have very little variation between groups for every day of the week. In contrast, activity profiles, 'at home and not sleeping' and 'away from home' were significantly different across groups for all days of the week.

Post-hoc tests showed that the differences between profiles were most significant between groups with different work status. Appendix B in the supplemental data online shows the results of comparing groups profiles against the group that coincides with the BREDEM family, 'Couple with dependent child(ren)/all working full time'. Profiles of households with occupants over 60 years of age who do not work full time, 'One person, over 60 years/not working full time' and 'Couple, over 60 years, no child(ren)/no one working full time', proved to be significantly different to the BREDEM family in all days of the week. Profiles of the group 'Lone parent with dependent child(ren)/not working full time' showed differences with the BREDEM family in most weekdays as well. In contrast, profiles of household where occupants work full time, 'One person, under 60 years/working full time' and 'Couple, under 60 years, no child(ren)/all working full time', showed differences in one or two days only. This suggests that work status is a determinant of the hours of occupancy in a household, which coincides with findings in literature. 
Table 8: Kruskal Wallis test results (i) - Comparison of occupancy profiles of each household group across days of the week.

\begin{tabular}{|c|c|c|c|}
\hline & $\begin{array}{l}\text { 'At home and } \\
\text { sleeping' }\end{array}$ & $\begin{array}{l}\text { 'At home \& not } \\
\text { sleeping' }\end{array}$ & 'Away from home' \\
\hline & $x^{2}$ & $x^{2}$ & $x^{2}$ \\
\hline $\begin{array}{l}\text { One person, over 6o / Not } \\
\text { working full time }\end{array}$ & $16.67^{*}$ & 10.18 & $37.83^{* * * *}$ \\
\hline $\begin{array}{l}\text { One person, under } 60 \text { / } \\
\text { Working full time }\end{array}$ & 12.31 & $42.05^{* * * *}$ & $18.71^{* *}$ \\
\hline $\begin{array}{l}\text { Couple with dependent } \\
\text { child(ren) / All working full } \\
\text { time }\end{array}$ & $29.34^{* * * *}$ & $22.46^{* * * *}$ & $22.41^{* *}$ \\
\hline $\begin{array}{l}\text { Couple with dependent } \\
\text { child(ren) / At least one } \\
\text { person working full time }\end{array}$ & $22.45^{* *}$ & $15.10^{*}$ & 11.63 \\
\hline $\begin{array}{l}\text { Couple, over } 60 \text {, no child(ren) } \\
\text { / No one working full time }\end{array}$ & 4.34 & 6.68 & $25.63^{* * *}$ \\
\hline $\begin{array}{l}\text { Couple, under 60, no } \\
\text { child(ren) / All working full } \\
\text { time }\end{array}$ & $15.11^{*}$ & $20.82^{* *}$ & $43.60^{* * * *}$ \\
\hline $\begin{array}{l}\text { Lone parent with dependent } \\
\text { child(ren) / Not working full } \\
\text { time }\end{array}$ & 1.28 & 10.42 & $60.50^{* * * *}$ \\
\hline $\begin{array}{l}\text { Note: }{ }^{*} p \text { value }<0.05 ;{ }^{* *} p \text { value }< \\
\text { there is a significant difference bet } \\
\text { those values of less than } 0.05\end{array}$ & $\begin{array}{l}\text { value }<0.00 \\
\text { profiles of } d\end{array}$ & $\begin{array}{l}e<0.0001 . A R \\
\text { for that group }\end{array}$ & $\begin{array}{l}0.05 \text { indicates that } \\
\text { te. Bold entries are }\end{array}$ \\
\hline
\end{tabular}

Table 9: Kruskal Wallis test results (ii)-Comparison of occupancy profiles of each day of the week across household groups.

\begin{tabular}{lccc}
\hline & 'At home and sleeping' & $\begin{array}{c}\text { 'At home \& not } \\
\text { sleeping' }\end{array}$ & 'Away from home' \\
\hline \multicolumn{1}{c}{$X^{2}$} & $X^{2}$ & $X^{2}$ \\
\hline Monday & 15.71 & $72.49^{* * * *}$ & $119.12^{* * * *}$ \\
\hline Tuesday & $19.38^{* *}$ & $105.15^{* * * *}$ & $139.47^{* * * *}$ \\
\hline Wednesday & $17.26^{* *}$ & $77.88^{* * * *}$ & $121.66^{* * * *}$ \\
\hline Thursday & 5.59 & $88.05^{* * * *}$ & $169.16^{* * * *}$ \\
\hline Friday & $17.28^{* *}$ & $109.04^{* * * *}$ & $90.85^{* * *}$ \\
\hline Saturday & 10.90 & $92.21^{* * * *}$ & $97.28^{* * *}$ \\
\hline Sunday & 7.17 & $66.36^{* * * *}$ & \\
\hline Note: ${ }^{*} p$ value $<0.05 ;{ }^{* *} p$ value $<0.01 ;{ }^{* * *} p$ value $<0.001 ;{ }^{* * * *} p$ value $<0.0001$. A p-value $<0.05$ indicates that \\
there is a significant difference between the profiles of different days for that group and state. Bold entries are \\
those values of less than 0.05
\end{tabular}


Furthermore, Appendix C in the supplemental data online shows the comparison of groups against the other commonly used profile, 'Couple, over 60 years, no child(ren)/no one working full time'. This analysis showed that there was no significant difference between the control group, 'Couple, over 60 years, no child(ren)/ no one working full time' and the group 'One person, over 60 years/not working full time'. In contrast, all other household groups showed significant differences on every day of the week. This suggests that the occupancy profiles of both groups may not need to be differentiated. These results can also be observed in Figures 8 and 9, particularly for Mondays-Fridays, where the dashed profile lines represent households where all occupants work full time. These profiles show similar shapes between each group and contrast with the continuous lines, which represent households where no one works full time. The exception is lone-parent households, whose profile follows a different trend.

Finally, Figures 7-9 show the resulting profiles of each household group by occupancy state for Mondays-Fridays, Saturdays and Sundays. The 24-hour time series with 10 minutes' resolution are available to download from Aragon, Gauthier, James, Anderson, and Warren (2017) and can be used as an input for simulation. 
State: At home and sleeping

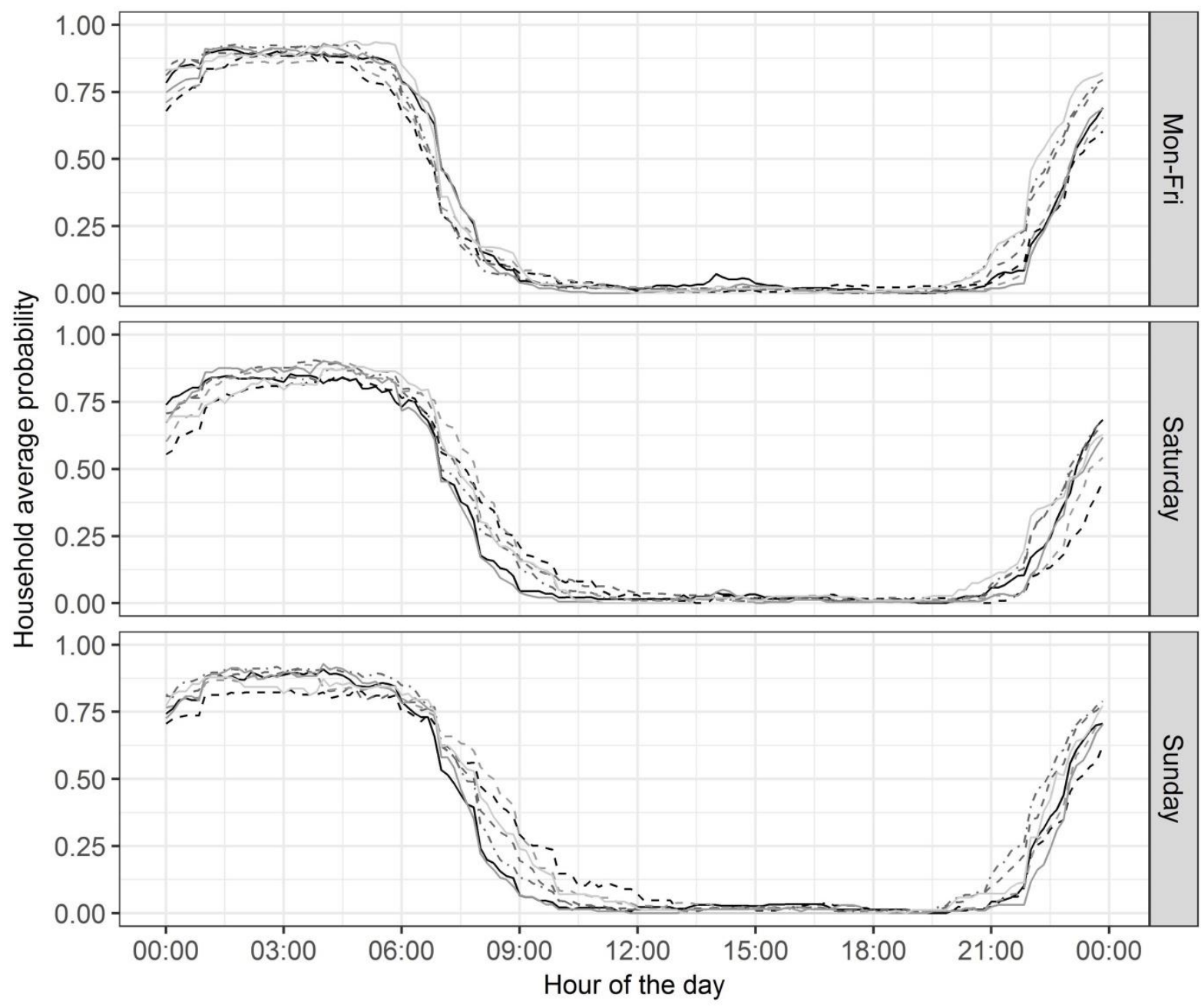

- One person, over 60 / Not working full time

- - - One person, under 60 / Working full time

- - Couple with dependent child(ren) / All working full time

... Couple with dependent child(ren) / At least one person working full time

$$
\begin{aligned}
& \text { Couple, over 60, no children / No one working } \\
& \text { full time } \\
& \text { - - Couple, under 60, no children / All working full } \\
& \text { time } \\
& \text { Lone parent with dependent child(ren) / Not } \\
& \text { working full time }
\end{aligned}
$$

Figure 7. Probability series of being at home and sleeping by household group and day of the week. Source: Derived from the UK Time Use Survey 2015 for England. 
State: At home and not sleeping

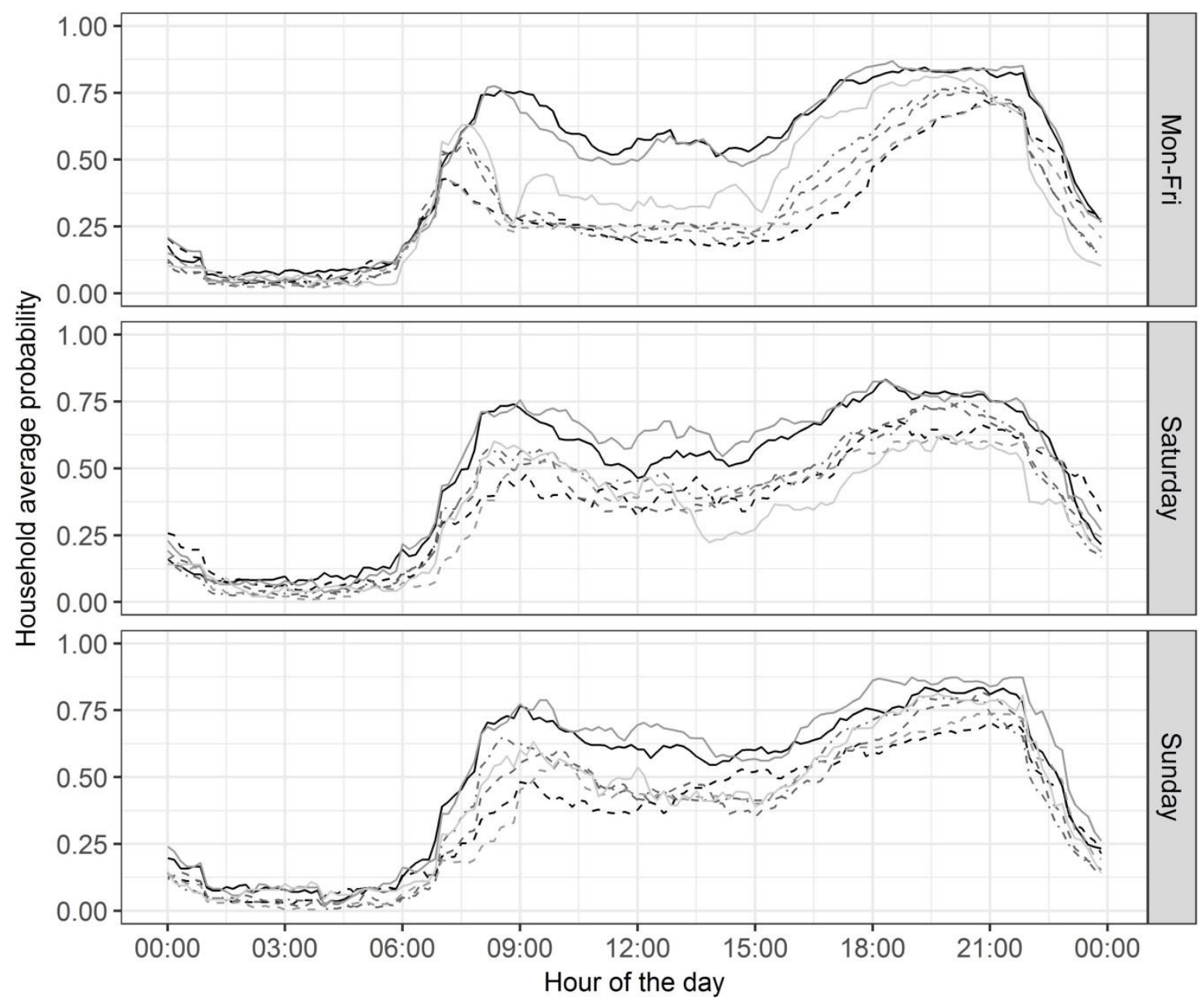

_ One person, over 60 / Not working full time

- - One person, under 60 / Working full time

- - - Couple with dependent child(ren) / All working full time

-.- Couple with dependent child(ren) / At least one person working full time

\footnotetext{
- Couple, over 60, no children / No one working full time

- - - Couple, under 60, no children / All working full time

Lone parent with dependent child(ren) / Not working full time
}

Figure 8. Probability of being at home and not sleeping by household group and day of the week. Source: Derived from the UK Time Use Survey 2015 for England. 
State: Away from home

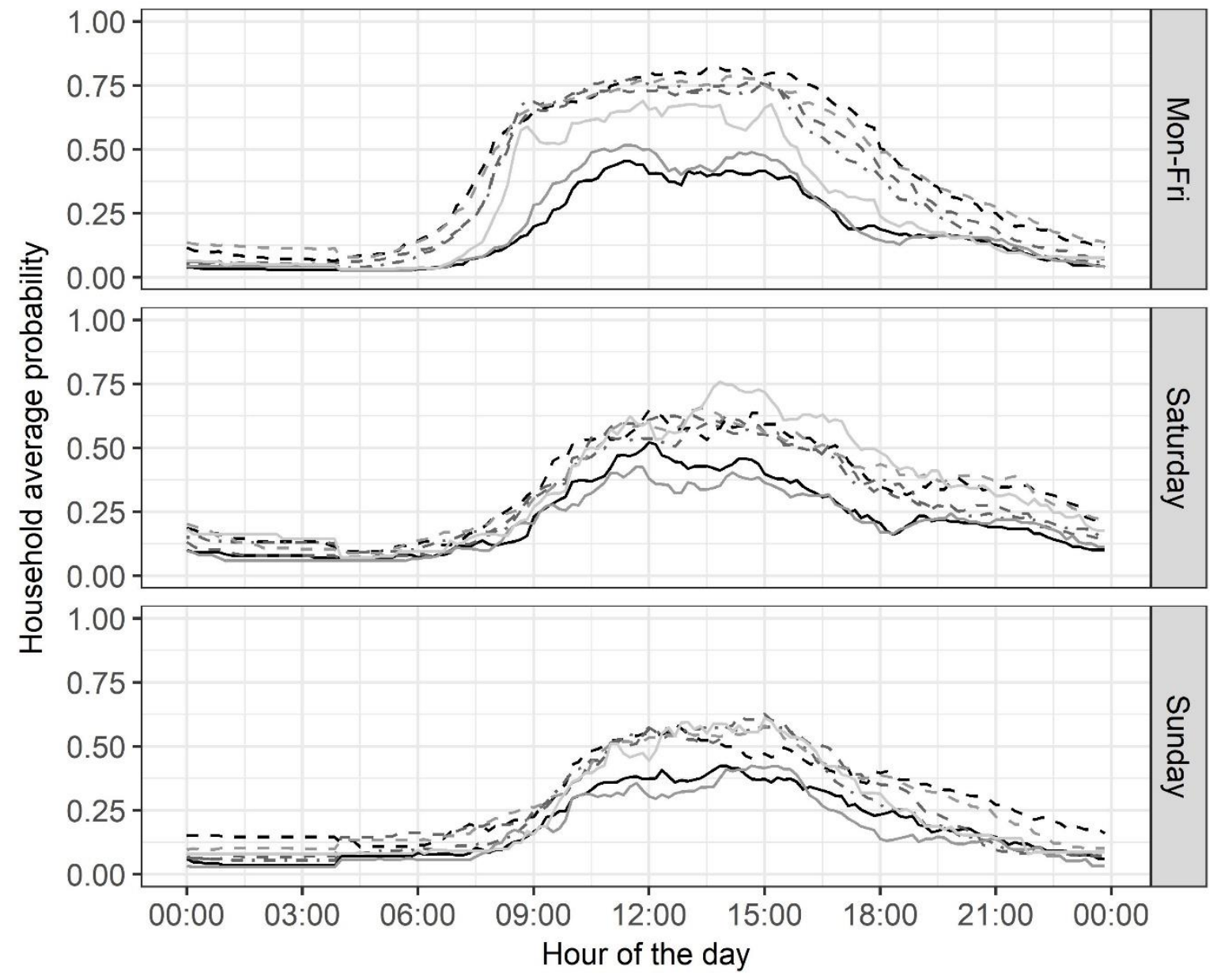

- One person, over 60 / Not working full time

- - One person, under 60 / Working full time

- - - Couple with dependent child(ren) / All working full time

.... Couple with dependent child(ren) / At least one person working full time

\footnotetext{
Couple, over 60, no children / No one working full time

- - - Couple, under 60, no children / All working full time

Lone parent with dependent child(ren) / Not working full time
}

Figure 9. Probability of being away from home by household group and day of the week.

Source: Derived from the UK Time Use Survey 2015 for England. 


\section{Discussion}

\subsection{Main findings and their implications}

The analysis of household typologies from the English Housing Survey interview sample uncovers a multiplicity of population groups and identifies the largest seven. This variability is currently not taken into account in the literature. The paper has found that the BREDEM household occupancy profile, which is the most used, represents only $6.2 \%$ of English households. Additionally, the second most common scenario, an elderly couple spending most of the day at home, represents $12.5 \%$. Groups such as working couples with no children, working singles or families where at least one adult does not work full time constitute more than $6 \%$ of the population each, and should be represented in energy demand and thermal comfort simulations.

This analysis assumes family composition and work status as the main determinants of occupant's activities based on prior findings in literature. This assumption was tested with patterns from the UK TUS. Occupancy proved to be significantly different across groups with different work status. Additionally, the presence of children in the family resulted in a decrease in daytime occupancy in comparison with couples with no children and singlepersons households.

Within the seven largest household groups, the group 'Couple with dependent children, all working full time' corresponds to the BREDEM scenario. During weekdays, the profile of this group shows peaks of activity in the home during the morning between 07:00 and 08:00 and during the evening from 16:00 to around 22:00 hours. This coincides with BREDEM occupancy patterns. During the weekend, the shape of the curves also shows peaks of activity in the mornings and evenings, contrasting with BREDEM's assumptions of full occupancy continuously through the weekend. Moreover, active occupancy probabilities are higher for Sundays than for Saturdays throughout the day.

The other common group 'Elderly couple who stays at home' can be compared against the groups 'Couple, over 60 years, no children/ no one working full time' and 'One person over 60 years/not working full time', which showed similar profiles, particularly on weekdays. Both groups show probabilities of household occupancy over $50 \%$ throughout 
the day. For couples, this suggests that most of the time there is at least one person in the house, which coincides with simulation assumptions for overheating analysis (Gupta \& Gregg, 2013; Mavrogianni et al., 2013; Porritt et al., 2010).

Time-use data were used in this study, as they are the largest UK data set available that has information on both household composition and people's activities. Even though the survey sample is designed to be representative, the reliability of these data can be questioned based on their format: self-completed diaries. Participants may not report the truth, perhaps due to 'observer bias' or because of not remembering their activities. Despite its limitations, TUSs are extensively used by fitting Markov models that simulate the 'randomness' of household occupancy. This approach is under continuous study and improvement from various research group across Europe.

For research on occupancy, there are currently no data-collection guidelines for assuring an accurate representation of what occurs in the homes. Data sets avail- able at the national or regional scales are not necessarily collected with occupancy in mind. Either national census and surveys need to incorporate occupancy in their question subjects or a set of methods must be defined to collect occupancy data at large scales.

At building or dwelling scale, occupancy can be monitored through a wide range of methods. A project's budget, the location and type of environment to be monitored, an occupant's privacy, the type of installation required and the level of detail necessary for the analysis are some of the factors to consider when choosing a method. Smart meters are an excellent example of a non-intrusive method that can be deployed at different scales. However, analysis of electricity demand requires complex analysis and high data resolution. Easily deployable sensors such as passive infrared (PIR) sensors (which have timed binary outputs) would be a suitable option for small studies.

Monitoring methods can be used on their own as an input of closed-loop or shortterm occupancy data in building management systems. Nevertheless, monitoring methods alone cannot capture the motivations for people's behaviour. To answer this limitation, social surveys can capture socio-demographic characteristics as well as the reasons for occupants' choices. Given that they provide subjective information, combining them with monitoring is also a way of testing the veracity of the survey. 
Despite the presence of methods to measure occupancy, it is an ethical challenge for researchers to gain access to and acceptance from residents to take part in studies that monitor their movements in their homes. Robust data are crucial to ensure that models accurately reflect energy-consumption patterns. Such evidence would enable the performance gap (the gap between modelled and actual energy consumption) to be reduced. There is a need to incorporate more representative behaviour profiles in models. This will allow better evaluation of energy demand-reduction options at the design stage. In the short-term, defining representative occupancy patterns is necessary to provide accurate data to standard models (such as the National Housing Model and the SAP in the UK) to generate reliable carbon emission and energy estimations. In the long-term, investigating how occupancy patterns might change as the energy system evolves from the impact of smart technologies, the integration of domestic demand-side responses and the impact of potential future heating systems are critical for policy development.

\subsection{Limitations}

The groups of domestic patterns were developed with the aim of being used in building research for energy demand and thermal comfort simulations. This guided the selection of occupancy states separating two states of occupancy within the household (sleeping and not sleeping). However, even though active presence can be an indicator of energy consumption, there are other factors to be considered. Energy consumption may be significantly affected by income level and both occupancy and the use and setting of heating/cooling systems may be guided by personal preferences.

The data set of patterns has further limitations. First, they are for England alone and other parts of the UK are not represented. Additionally, schedules were not differentiated by season but are a yearly average. What is more, patterns were derived from data from 2014-15 only, which is the latest TUS for the UK. Reported occupancy could be biased by events of that year such as heatwaves or very low temperatures, or level of employment. Large-scale studies such as population census are implemented every 10 years to capture changes in socio-demographic factors. In the UK, the previous TUS was in 2000-01 and how these changes have impacted on occupancy since has not been quantified. 
Regarding the validity of the data set used, the UK TUS 2014-15 follows a standardized structure for sampling, data collection and coding, which assures the quality of the data. However, the information is still subjective to each respondent. The English Housing Survey 2014-15 also follows a standardized design, being comparable across studies of different years. Its design can be questioned on the basis that tenure is used as the main factor to assure national representation.

In relation to how the data set was analysed, it must be kept in mind that both KruskalWallis and Dunn's post- hoc comparison tests for differences in the distribution of the data only and do not evaluate shape. Further analysis is needed to compare the curves of each group's occupancy profile in more detail, particularly to analyse differences between days of the week. This could also allow comparing at what times occupancy peaks and lows occur and to identify the specific behaviour of each group.

\section{Conclusions}

This paper evaluates the state of knowledge on domestic occupancy and developed representative patterns for the UK. It also questions the use of the BREDEM pattern as the most common occupancy profile, showing that it only represents $6.2 \%$ of English households alone. This implies that current estimations of energy demand and thermal comfort analysis are limited in scope in terms of their predictions. These findings are relevant to building researchers as well as policy-makers as they contribute to reducing the energy performance gap through a better understanding of occupant behaviour.

The review of the literature showed that occupancy data collection at the building scale is highly varied. It is important for researchers to evaluate the final use of the data as well as the characteristics of the environment of analysis to define what information is needed. Large- scale data-collection methods are an important knowledge gap, as there are no standard procedures to capture occupancy in building research. Occupancy is and can be derived from TUSs; however, this method was not designed with building research in mind.

Finally, the set of high-resolution time series developed in this paper can be applied to building simulation. This set represents the seven largest population groups based on the family composition and work status of occupants in England. 


\section{Disclosure statement}

No potential conflict of interest was reported by the authors

\section{Funding}

This work was supported by the H2020-EEB-2016 European project [grant number 723562 (THERMOSS)]. It was also supported by a project on occupancy patterns supported by the former UK Department of Energy and Climate Change (DECC) (University of Southampton (UoS), 2016) (see https://www.gov.uk/government/publications/scoping-review-ofoccupancy-patterns )

\section{References}

Aerts, D., Minnen, J., Glorieux, I., Wouters, I., \& Descamps, F. (2014). A method for the identification and modelling of realistic domestic occupancy sequences for building energy demand simulations and peer comparison. Building and Environment, 75, 67-78. doi:10.1016/j.buildenv.2014.01.021

Agarwal, Y., Balaji, B., Gupta, R., Lyles, J., Wei, M., \& Weng, T. (2010). Occupancy-driven energy management for smart building automation. In Proceedings of the 2nd ACM Workshop on Embedded Sensing Systems for Energy- Efficiency in Building, BuildSys '10, pp. 1-6, New York, NY, US. ACM. doi:10.1145/1878431.1878433

Ahmed, N. K., Atiya, A. F., Gayar, N. E., \& El-Shishiny, H.(2010). An empirical comparison of machine learning models for time series forecasting. Econometric Reviews, 29(5-6), 594-621. doi:10.1080/07474938.2010.481556

Ai, B., Fan, Z., \& Gao, R. X. (2014). Occupancy estimation for smart buildings by an auto-regressive hidden Markov model. Proceedings of the American Control Conference, pp. 2234-2239. doi:10.1109/ACC.2014.6859372

Akbar, A., Nati, M., Carrez, F., \& Moessner, K. (2015). Contextual occupancy detection for smart office by pattern recognition of electricity consumption data. IEEE International Conference on Communications, September 2015: 561-566. doi:10.1109/ICC.2015.7248381

Al-Fuqaha, A., Guizani, M., Mohammadi, M., Aledhari, M., \& Ayyash, M. (2015). Internet of things: A survey on enabling technologies, protocols, and applications. IEEE Communications Surveys and Tutorials, 17(4), 2347-2376. doi:10.1109/COMST.2015.2444095

Albert, A., \& Rajagopal, R. (2013). Smart meter driven segmentation: What your consumption says about you. IEEE Transactions on Power Systems, 28(4), 4019-4030. doi:10. 1109/TPWRS.2013.2266122

Alitajer, S., \& Molavi Nojoumi, G. (2016). Privacy at home: Analysis of behavioral patterns in the spatial configuration of traditional and modern houses in the city of Hamedan based on the notion of space syntax. Frontiers of Architectural Research, 5(3), 341-352.

doi:10.1016/j.foar.2016.02.003 
Alsheikh, M. A., Lin, S., Niyato, D., \& Tan, H. P. (2014). Machine learning in wireless sensor networks: Algorithms, strategies, and applications. IEEE Communications Surveys Tutorials, 16(4), 19962018. doi:10.1109/COMST.2014.2320099

Anderson, B., Chapman, P. F., Cutland, N. G., Dickson, C. M., Doran, S. M., Henderson, G.,...Shorrock, L. D. (2008). BREDEM-12 Model Description 2001 update. Technical report, BRE, DEFRA. http://www.iea.org/media/statistics/eemanual/UK BREDEM model description.pdf

Anderson, B., Lin, S., Newing, A., Bahaj, A., \& James, P. (2017). Electricity consumption and household characteristics: Implications for census-taking in a smart metered future. Computers, Environment and Urban Systems, 63, 58-67. doi:10.1016/j.compenvurbsys.2016.06.003

Aragon, V., Gauthier, S., James, P., Anderson, B., \& Warren, P. (2017). England's domestic occupancy patterns. Southampton: University of Southampton. doi:10.5258/ SOTON/D0142 [Data set].

Baker, K. J., \& Rylatt, R. M. (2008). Improving the prediction of UK domestic energy demand using annual consumption-data. Applied Energy, 85(6), 475-482. doi:10.1016/j. apenergy.2007.09.004

Beizaee, A., Allinson, D., Lomas, K. J., Foda, E., \& Loveday, D.L. (2015). Measuring the potential of zonal space heating controls to reduce energy use in UK homes: The case of un-furbished 1930s dwellings. Energy and Buildings, 92, 29-44. doi:10.1016/j.enbuild.2015.01.040

Bian, X., Abowd, G. D., \& Rehg, J. M. (2005). Using sound source localization in a home environment. In Gellersen, H. W., Want, R., and Schmidt, A., editors, Pervasive Computing: Third International Conference, PERVASIVE 2005, Munich, Germany, May 8-13, 2005. Proceedings, pp. 19-36. Springer Berlin Heidelberg, Berlin, Heidelberg. doi:10.1007/11428572_2

Bourikas, L., Costanza, E., Gauthier, S., James, P. A. B., Kittley-Davies, J., Ornaghi, C.,...Huang, Y. (2017). Camera based window opening estimation in a naturally ventilated office. Building Research \& Information, 110(0), 1-16. doi:10.1080/09613218.2016.1245951

Cali, D., Matthes, P., Huchtemann, K., Streblow, R., \& Müller,D. (2015). CO2 based occupancy detection algorithm: Experimental analysis and validation for office and residential buildings. Building and Environment, 86, 39-49. doi:10. 1016/j.buildenv.2014.12.011

Chaney, J., Hugh Owens, E., \& Peacock, A. D. (2016). An evidence based approach to determining residential occupancy and its role in demand response management. Energy and Buildings, 125, 254-266. doi:10.1016/j. enbuild.2016.04.060

Chau, J. Y., Merom, D., Grunseit, A., Rissel, C., Bauman, A. E.,\& Van Der Ploeg, H. P. (2012). Temporal trends in non- occupational sedentary behaviours from Australian time Use surveys 1992, 1997 and 2006. International Journal of Behavioral Nutrition and Physical Activity, 9, 76. doi:10. $1186 / 1479-5868-9-76$

Chen, D., Barker, S., Subbaswamy, A., Irwin, D., \& Shenoy, P. (2013). Non-intrusive occupancy monitoring using smart meters. In Proceedings of the 5th ACM Workshop on Embedded Systems For Energy-Efficient Buildings, BuildSys'13, pp. 9:1-9:8, New York, NY, US. ACM. doi:10. $1145 / 2528282.2528294$

Cheng, V., \& Steemers, K. (2011). Modelling domestic energy consumption at district scale: A tool to support national and local energy policies. Environmental Modelling \& Software, 26(10), 11861198. doi:10.1016/j.envsoft.2011.04.005

Department for Communities and Local Government (DCLG). (2015a). English Housing Survey technical report. London: DCLG. 
Department for Communities and Local Government (DCLG). (2017). English Housing Survey, 2015: Housing stock data. [data collection] 4th Edition. London: DCLG. Retrieved from UK Data Service. http://doi.org/10.5255/ UKDA-SN-8010-4

Dodier, R. H., Henze, G. P., Tiller, D. K., \& Guo, X. (2006). Building occupancy detection through sensor belief net-works. Energy and Buildings, 38(9), 1033-1043. doi:10.1016/j.enbuild.2005.12.001

Dong, B., Andrews, B., Lam, K. P., Höynck, M., Zhang, R., Chiou, Y.-S., \& Benitez, D. (2010). An information technology enabled sustainability test-bed (ITEST) for occupancy detection through an environmental sensing network. Energy and Buildings, 42(7), 1038-1046. doi:10.1016/j.enbuild.2010.01.016

Dong, B., \& Lam, K. P. (2014). A real-time model predictive control for building heating and cooling systems based onthe occupancy behavior pattern detection and local weather forecasting. Building Simulation, 7(1), 89-106. doi:10.1007/ s12273-013-0142-7

EUROSTAT. (2004). Harmonised European time use surveys: 2008 Guidelines. Technical report, Luxembourg. Retrieved from European Commission:

http://ec.europa.eu/eurostat/ramon/statmanuals/files/KS-RA-08-014-EN.pdf

Flett, G., \& Kelly, N. (2016). An occupant-differentiated, higher-order Markov chain method for prediction of dom- estic occupancy. Energy and Buildings, 125, 219-230. doi:10.1016/j.enbuild.2016.05.015

Gaetani, I., Hoes, P.-J., \& Hensen, J. L. (2016). Occupant behavior in building energy simulation: Towards a fit-for-purpose modeling strategy. Energy and Buildings, 121, 188-204. doi:10.1016/j.enbuild.2016.03.038

Gauthier, S., \& Shipworth, D. (2015). Behavioural responses to cold thermal discomfort. Building Research \& Information, 43(3), 355-370. doi:10.1080/09613218.2015.1003277

Gershuny, J. (2011). Time-use surveys and the measurement of national well-being. Technical report, Centre for Time Use Research, University of Oxford, Office for National Statistics, London. Retrieved from Office for National Statistics: http://webarchive.nationalarchives.gov.uk/20160105160709/http://www.ons.gov.uk/ons/rel/e nvironmental/time-use-surveys-and-the-measurement-of-national-well-being/article-byjonathan-gershuny/index.html

Gershuny, J., \& Sullivan, O. (2017). United Kingdom Time Use Survey, 2014-2015. [data collection]. Retrieved from: http://doi.org/10.5255/UKDA-SN-8128-1

Government Office for Science. (2016). Future of an ageing population. Technical report, Government Office for Science, London. Retrieved from GOV.UK: https://www.gov.uk/government/publications/future-of-an-ageing-population

Gram-Hanssen, K. (2010). Residential heat comfort practices: Understanding users. Building Research \& Information, 38 (2), 175-186. doi:10.1080/09613210903541527

Guerra-Santin, O., \& Itard, L. (2010). Occupants' behaviour: Determinants and effects on residential heating consump-tion. Building Research \& Information, 38(3), 318-338. doi:10.1080/09613211003661074

Gupta, R., \& Gregg, M. (2013). Preventing the overheating of English suburban homes in a warming climate. Building Research \& Information, 41(3), 281-300.

doi:10.1080/09613218.2013.772043 
Hong, T., Taylor-Lange, S. C., D’Oca, S., Yan, D., \& Corgnati, S. P. (2016). Advances in research and applications of energy-related occupant behavior in buildings. Energy and Buildings, 116, 694-702. doi:10.1016/j. enbuild.2015.11.052

Howard, J., \& Hoff, W. (2013). Forecasting building occupancy using sensor network data. In Proceedings of the 2Nd International Workshop on Big Data, Streams and Heterogeneous Source Mining: Algorithms, Systems, Programming Models and Applications, BigMine '13, pages 87-94, New York, NY, US. ACM. doi:10.1145/ 2501221.2501233

Huebner, G. M., Hamilton, I., Chalabi, Z., Shipworth, D., \& Oreszczyn, T. (2015). Explaining domestic energy consumption - The comparative contribution of building factors, sociodemographics, behaviours and attitudes. Applied Energy, 159, 589-600. doi:10.1016/j.apenergy.2015.09.028

Jia, M., Srinivasan, R. S., \& Raheem, A. A. (2017). From occupancy to occupant behavior: An analytical survey of data acquisition technologies, modeling methodologies and simulation coupling mechanisms for building energy efficiency. Renewable and Sustainable Energy Reviews, 68, 525-540. doi;10.1016/j.rser.2016.10.011

Kleiminger, W., Beckel, C., Staake, T., \& Santini, S. (2013). Occupancy detection from electricity consumption data. In Proceedings of the 5th ACM Workshop on Embedded Systems For EnergyEfficient Buildings (BuildSys'13). ACM, New York, NY, US, Article 10, 8 pages doi:10.1145/2528282.2528295

Lazik, P., \& Shih, O. (2015). ALPS : A Bluetooth and ultra- sound platform for mapping and localization. ACM SenSys, 73-84. do10.1145/2809695.2809727

Li, H., Zhang, Q., \& Duan, P. (2008). A novel one-pass neural network approach for activities recognition in intelligent environments. In 2008 7th World Congress on Intelligent Control and Automation, pp. 50-54. doi:10.1109/WCICA. 2008.4592901

Mahmoud, S. M., Lotfi, A., \& Langensiepen, C. (2010). Occupancy pattern extraction and prediction in an inhabited intelligent environment using NARX Networks. doi:10.1109/IE.2010.18

Marshall, E., Steinberger, J. K., Dupont, V., \& Foxon, T. J. (2016). Combining energy efficiency measure approachesand occupancy patterns in building modelling in the UK residential context. Energy and Buildings, 111, 98-108. doi:10.1016/j.enbuild.2015.11.039

Mavrogianni, A., Davies, M., Taylor, J., Chalabi, Z., Biddulph, P., Oikonomou, E., ... Jones, B. (2014). The impact of occupancy patterns, occupant-controlled ventilation and shading on indoor overheating risk in domestic environments. Building and Environment, 78, 183-198. doi:10.1016/j. buildenv.2014.04.008

McKenna, E., Krawczynski, M., \& Thomson, M. (2015). Four- state domestic building occupancy model for energy demand simulations. Energy and Buildings, 96, 30-39. doi:10.1016/j.enbuild.2015.03.013

McMichael, M. H. (2011). Social capital and the diffusion of energy-reducing innovations in UK Households (PhD the- sis). UCL (University College London).

Morris, A. S., Humphrey, A., Alvarez, P. C., \& Lima, O. D. (2016). The UK time diary study 2014-2015 Technical Report. Naghiyev, E., Gillott, M., \& Wilson, R. (2014). Three unobtrusive domestic occupancy measurement technologies under qualitative review. Energy and Buildings, 69, 507514. doi:10.1016/j.enbuild.2013.11.033

Nicol, F., \& Spires, B. (2013). The limits of thermal comfort: Avoiding overheating in European buildings TM52: 2013. The Chartered Institution of Building Services Engineers London. 
Office for National Statistics (ONS). (2016a). Families and households [data set]. Retrieved from https://www.ons.gov.uk/peoplepopulationandcommunity/birthsdeathsandmarriages/families/ datasets/familiesandhouseholdsfamiliesandhouseholds

Office for National Statistics (ONS). (2016b). Young adults aged 15-34 living with their parents by age and sex, UK, 1996 to 2016 [data set]. Retrieved from https://www.ons.gov.uk/peoplepopulationandcommunity/birthsdeathsandmarriages/families/ datasets/familiesandhouseholdsfamiliesandhouseholds

Parent-Thirion, A., Macias, E. F., Hurley, J., \& Vermeylen, G. (2007). Fourth European working conditions survey. Technical report, European Foundation for the Improvement of Living and Working Conditions, Luxembourg. Retrieved from Eurofound: https://www.eurofound.europa.eu/publications/report/2007/workingconditions/fourtheuropean-working-conditions-survey

Patel, A. N., Reynolds, M. S., \& Abowd, G. D. (2008). Detecting human movement by differential air pressure sensing in HVAC system ductwork: An exploration in infrastructure mediated sensing. In proceeding of Pervasive 2008: Pervasive Computing, pp. 1-18.

Perera, C., Zaslavsky, A., Christen, P., \& Georgakopoulos, D. (2014). Context aware computing for The internet of things: A survey. IEEE Communications Surveys \& Tutorials, 16(1), 414-454. doi:10.1109/SURV.2013.042313.00197

Porritt, S. M., Shao, L., Cropper, P. C., \& Goodier, C. I. (2010). Building orientation and occupancy patterns and their effect on interventions to reduce overheating in dwellings during heat waves. In IESD PhD Conference: Energy and Sustainable Development, number May, pp. 1-14. doi: https://dspace.Iboro.ac.uk/2134/9772

Prevost, G., Baetz, B. W., Razavi, S., \& El-Dakhakhni, W. (2015). Retrofitting suburban homes for resiliency: Design principles. Journal of Urban Planning and Development, 141(3), 04014027. doi:10.1890/05-2018

Richardson, I., Thomson, M., \& Infield, D. (2008). A high-resolution domestic building occupancy model for energy demand simulations. Energy and Buildings, 40(8), 1560- 1566. doi:10.1016/j.enbuild.2008.02.006

Rodriguez, A., \& Shala, U. (2011). Indoor positioning using sensor-fusion in Android devices. doi:10.1.1.367.2683

Sailer, K., Pomeroy, R., \& Haslem, R. (2015). Data-driven design using data on human behaviour and spatial configuration to inform better workplace design. Corporate Real Estate Journal, 4(3), 249-262. http://discovery.ucl.ac.uk/id/eprint/1465065

Spataru, C., \& Gauthier, S. (2014). How to monitor people 'smartly' to help reducing energy consumption in buildings? Architectural Engineering and Design Management, 10(1-2), 60-78. doi:10.1080/17452007.2013.837248

Spataru, C., Gillott, M., \& Hall, M. R. (2010). Domestic energy and occupancy: A novel postoccupancy evaluation study. International Journal of Low-Carbon Technologies, 5, 148-157. doi:10.1093/ijlct/ctq020

Sturari, M., Liciotti, D., Pierdicca, R., Frontoni, E., Mancini, A., Contigiani, M., \& Zingaretti, P. (2016). Robust and afford-able retail customer profiling by vision and radio beacon sensor fusion. Pattern Recognition Letters, 81, 30-40. doi:10.1016/j.patrec.2016.02.010 
University of Southampton (UoS). (2016). Occupancy patterns scoping review project. Technical Report Low Carbon Technologies and Household Energy. London: Department of Energy and Climate Change (DECC). Retrieved from GOV.UK: https://www.gov.uk/government/publications/scoping-review-of-occupancy-patterns

Widen, J., Nilsson, A. M., \& Wäckelgård, E. (2009). A combined Markov chain and bottom-up approach to modelling of domestic lighting demand. Energy and Buildings, 41(10), 1001-1012. doi:10.1016/j.enbuild.2009.05.002

Wilke, U., Haldi, F., Scartezzini, J.-L., \& Robinson, D. (2013). A bottom-up stochastic model to predict building occupants' time dependent activities. Building and Environment, 60, 254-264. doi:10.1016/j.buildenv.2012.10.021

Xiong, J., \& Jamieson, K. (2013). ArrayTrack: A fine-grained indoor location system. In Presented as part of the 10th USENIX Symposium on Networked Systems Design and Implementation (NSDI 13), pp. 71-84, Lombard, IL. USENIX. https://www.usenix.org/conference/nsdi13/technicalsessions/presentation/xiong

Yao, R., \& Steemers, K. (2005). A method of formulating energy load profile for domestic buildings in the UK. Energy and Buildings, 37(6), 663-671. doi:10.1016/j. enbuild.2004.09.007

Yohanis, Y. G., Mondol, J. D., Wright, A., \& Norton, B. (2008). Real-life energy use in the UK: How occupancy and dwelling characteristics affect domestic electricity use. Energy and Buildings, 40(6), 1053-1059. doi:10.1016/j.enbuild.2007.09.001

Zhang, C., \& Jia, Q. S. (2016). A review of occupant behavior models in residential building: Sensing, modeling, and prediction. Proceedings of the 28th Chinese Control and Decision Conference, CCDC 2016, pp. 2032-2037. doi:10. 1109/CCDC.2016.7531318

Zhang, T., Siebers, P.-O., \& Aickelin, U. (2012). A three- dimensional model of residential energy consumer arche- types for local energy policy design in the UK. Energy Policy, 47, 102-110. doi:10.1016/j.enpol.2012.04.027

Zhao, J., Lasternas, B., Lam, K. P., Yun, R., \& Loftness, V. (2014). Occupant behavior and schedule modeling for building energy simulation through office appliance power consumption data mining. Energy and Buildings, 82, 341-355. doi:10.1016/j.enbuild.2014.07.033 


\section{APPENDIX A}

Appendix A: Post hoc multiple comparison test results (i) - Comparison of occupancy profiles of each household group across days of the week using Saturday as control. An observed difference of more than the critical value set by the test (90.52), at 0.05 significance level, indicates that the profile of that group on that day is significantly different from the Saturday profile for the same group.

\begin{tabular}{|c|c|c|c|c|c|c|c|}
\hline \multicolumn{8}{|c|}{ Observed difference against control group (Critical difference: 90.52) } \\
\hline \multicolumn{8}{|c|}{ State: 'at home and sleeping' } \\
\hline & Mon & Tue & Wed & Thurs & Fri & Sat & Sun \\
\hline $\begin{array}{l}\text { One person, over } 60 \text { / Not working } \\
\text { full time }\end{array}$ & 32.6 & 49.07 & 83.16 & 2.64 & 25.26 & - & 24.12 \\
\hline $\begin{array}{l}\text { One person, under } 60 \text { / Working } \\
\text { full time }\end{array}$ & 58.3 & 46.91 & 8.59 & 22.01 & 8.39 & - & 42.72 \\
\hline $\begin{array}{l}\text { Couple with dependent child(ren) / } \\
\text { All working full time }\end{array}$ & 105.99 & 49.4 & 4.67 & 19.21 & 134.73 & - & 12.37 \\
\hline $\begin{array}{l}\text { Couple with dependent child(ren) / } \\
\text { At least one person working full } \\
\text { time }\end{array}$ & 46.37 & 64.71 & 30.12 & 58.28 & 52.63 & - & 49.35 \\
\hline $\begin{array}{l}\text { Couple, over } 60 \text {, no child(ren) / } \\
\text { No one working full time }\end{array}$ & 21.38 & 21.08 & 39.37 & 9.21 & 10.8 & - & 20.49 \\
\hline $\begin{array}{l}\text { Couple, under } 60 \text {, no child(ren) / } \\
\text { All working full time }\end{array}$ & 35.54 & 1.89 & 11.94 & 23.99 & 6.72 & - & 42 \\
\hline $\begin{array}{l}\text { Lone parent with dependent } \\
\text { child(ren) / } \\
\text { Not working full time }\end{array}$ & 1.64 & 28.1 & 2.47 & 1.61 & 1.38 & - & 0.48 \\
\hline \multicolumn{8}{|c|}{ State 'at home and not sleeping' } \\
\hline & Mon & Tue & Wed & Thurs & Fri & Sat & Sun \\
\hline $\begin{array}{l}\text { One person, over } 60 \text { / Not } \\
\text { working full time }\end{array}$ & 65.54 & 33.46 & 26.97 & 40.14 & 51.73 & - & 20.48 \\
\hline $\begin{array}{l}\text { One person, under } 60 \text { / Working } \\
\text { full time }\end{array}$ & 90.43 & 173.62 & 57.06 & 145.92 & 105.77 & - & 16.26 \\
\hline $\begin{array}{l}\text { Couple with dependent child(ren) } \\
\text { / } \\
\text { All working full time }\end{array}$ & 38.06 & 101.03 & 121.08 & 70.53 & 73.83 & - & 1.26 \\
\hline $\begin{array}{l}\text { Couple with dependent child(ren) } \\
\text { / } \\
\text { At least one person working full } \\
\text { time }\end{array}$ & 33.83 & 81.48 & 76.85 & 83.52 & 81.91 & - & 2.17 \\
\hline $\begin{array}{l}\text { Couple, over } 60 \text {, no child(ren) / } \\
\text { No one working full time }\end{array}$ & 40.18 & 16.89 & 16.49 & 46.71 & 4.02 & - & 26.66 \\
\hline $\begin{array}{l}\text { Couple, under } 60, \text { no child(ren) / } \\
\text { All working full time }\end{array}$ & 47.24 & 53.51 & 114.83 & 63.1 & 93.66 & - & 8.96 \\
\hline $\begin{array}{l}\text { Lone parent with dependent } \\
\text { child(ren) / Not working full time }\end{array}$ & 27.76 & 55.14 & 66.71 & 17.12 & 17.69 & - & 89.24 \\
\hline
\end{tabular}




\begin{tabular}{|c|c|c|c|c|c|c|c|}
\hline \multicolumn{8}{|c|}{ State 'away from home' } \\
\hline & Mon & Tue & Wed & Thurs & Fri & Sat & Sun \\
\hline $\begin{array}{l}\text { One person, over } 60 \text { / Not working } \\
\text { full time }\end{array}$ & 178.63 & 104.85 & 38.57 & 127.03 & 136.00 & - & 78.99 \\
\hline $\begin{array}{l}\text { One person, under } 60 \text { / Working } \\
\text { full time }\end{array}$ & 0.2 & 58.31 & 18.33 & 92.67 & 55.45 & - & 31.25 \\
\hline $\begin{array}{l}\text { Couple with dependent child(ren) / } \\
\text { All working full time }\end{array}$ & 9.04 & 13.31 & 52.83 & 53.06 & 99.61 & & 39.38 \\
\hline $\begin{array}{l}\text { Couple with dependent child(ren) / } \\
\text { At least one person working full } \\
\text { time }\end{array}$ & 60.26 & 0.92 & 8.98 & 37.05 & 0.27 & - & 83.46 \\
\hline $\begin{array}{l}\text { Couple, over } 60, \text { no child(ren) / } \\
\text { No one working full time }\end{array}$ & 7.1 & 91.11 & 71.39 & 47.17 & 125.1 & - & 98.53 \\
\hline $\begin{array}{l}\text { Couple, under } 60, \text { no child(ren) / } \\
\text { All working full time }\end{array}$ & 11.37 & 59.94 & 96.6 & 17.58 & 123.09 & - & 64.41 \\
\hline $\begin{array}{l}\text { Lone parent with dependent } \\
\text { child(ren) / Not working full time }\end{array}$ & 39.1 & 172.83 & 193.33 & 165.39 & 52.5 & - & 142.93 \\
\hline
\end{tabular}




\section{APPENDIX B}

Appendix B: Post hoc multiple comparison test results (ii) - comparison of daily occupancy profiles across household groups, using 'Couple with dependent child(ren) / All working full time' as control. An observed difference of more than the critical value set by the test (90.52), at 0.05 significance level, indicates that the profile of that group for that day is significantly different from the control household group for the same day.

Observed difference against control group (Critical difference: 90.52)

\begin{tabular}{|c|c|c|c|c|c|c|c|}
\hline \multicolumn{8}{|c|}{ State: 'at home and sleeping' } \\
\hline & $\begin{array}{l}\text { One person, } \\
\text { over } 60 \text { / } \\
\text { Not working } \\
\text { full time }\end{array}$ & $\begin{array}{l}\text { One person, } \\
\text { under } 60 \text { / } \\
\text { Working full } \\
\text { time }\end{array}$ & $\begin{array}{l}\text { Couple with } \\
\text { dependent } \\
\text { child(ren) / } \\
\text { All working full } \\
\text { time }\end{array}$ & $\begin{array}{l}\text { Couple with } \\
\text { dependent } \\
\text { child(ren) / } \\
\text { At least one } \\
\text { person working } \\
\text { full time }\end{array}$ & $\begin{array}{l}\text { Couple, over } \\
60, \text { no } \\
\text { child(ren) / } \\
\text { No one } \\
\text { working full } \\
\text { time }\end{array}$ & $\begin{array}{l}\text { Couple, under } \\
60, \text { no } \\
\text { child(ren) / } \\
\text { All working } \\
\text { full time }\end{array}$ & $\begin{array}{l}\text { Lone parent } \\
\text { with } \\
\text { dependent } \\
\text { child(ren) / } \\
\text { Not working } \\
\text { full time }\end{array}$ \\
\hline Mon & 78.65 & 83.29 & - & 97.78 & 6.39 & 80 & 63.57 \\
\hline Tue & 51.05 & 49.72 & - & 57.73 & 44.62 & 6.67 & 33.34 \\
\hline Wed & 31.64 & 58.4 & - & 54.92 & 91.72 & 51.89 & 36.22 \\
\hline Thurs & 40.49 & 16.27 & - & 19.3 & 47.63 & 10.15 & 28.45 \\
\hline Fri & 114.48 & 102.12 & - & 47.18 & 55.42 & 48.9 & 102.2 \\
\hline Sat & 54.4 & 62.37 & - & 61.99 & 112.44 & 56 & 51.14 \\
\hline Sun & 5.2 & 2.99 & - & 20.17 & 53.62 & 8.94 & 39.58 \\
\hline \multicolumn{8}{|c|}{ State: 'at home and not sleeping' } \\
\hline & $\begin{array}{l}\text { One person, } \\
\text { over } 60 \text { / } \\
\text { Not working } \\
\text { full time }\end{array}$ & $\begin{array}{l}\text { One person, } \\
\text { under } 60 \text { / } \\
\text { Working full } \\
\text { time }\end{array}$ & $\begin{array}{l}\text { Couple with } \\
\text { dependent } \\
\text { child(ren) / } \\
\text { All working full } \\
\text { time }\end{array}$ & $\begin{array}{l}\text { Couple with } \\
\text { dependent } \\
\text { child(ren) / } \\
\text { At least one } \\
\text { person working } \\
\text { full time }\end{array}$ & $\begin{array}{l}\text { Couple, over } \\
60, \text { no } \\
\text { child(ren) / } \\
\text { No one } \\
\text { working full } \\
\text { time }\end{array}$ & $\begin{array}{l}\text { Couple, under } \\
60, \text { no } \\
\text { child(ren) / } \\
\text { All working } \\
\text { full time }\end{array}$ & $\begin{array}{l}\text { Lone parent } \\
\text { with } \\
\text { dependent } \\
\text { child(ren) / } \\
\text { Not working } \\
\text { full time }\end{array}$ \\
\hline Mon & 117.95 & 40.71 & - & 4.39 & 128.53 & 36.34 & 12.59 \\
\hline Tue & 207.9 & 50.28 & - & 11.07 & 196.42 & 7.54 & 86.83 \\
\hline Wed & 185.21 & 69.17 & - & 35.99 & 201.72 & 16.98 & 128.63 \\
\hline Thurs & 188.11 & 58.75 & - & 16.38 & 147.06 & 22.01 & 32.3 \\
\hline Fri & 204.86 & 15.25 & - & 4.98 & 195 & 47.69 & 50.61 \\
\hline Sat & 161.93 & 3.03 & - & 24.33 & 192.31 & 33.3 & 47.64 \\
\hline Sun & 143.33 & 15.77 & - & 10.12 & 178.26 & 23.93 & 43.11 \\
\hline \multicolumn{8}{|c|}{ State: 'away from home' } \\
\hline & $\begin{array}{l}\text { One person, } \\
\text { over } 60 \text { / } \\
\text { Not working } \\
\text { full time }\end{array}$ & $\begin{array}{l}\text { One person, } \\
\text { under } 60 \text { / } \\
\text { Working full } \\
\text { time }\end{array}$ & $\begin{array}{l}\text { Couple with } \\
\text { dependent } \\
\text { child(ren) / } \\
\text { All working full } \\
\text { time }\end{array}$ & $\begin{array}{l}\text { Couple with } \\
\text { dependent } \\
\text { child(ren) / } \\
\text { At least one } \\
\text { person working } \\
\text { full time }\end{array}$ & $\begin{array}{l}\text { Couple, over } \\
60, \text { no } \\
\text { child(ren) / } \\
\text { No one } \\
\text { working full } \\
\text { time }\end{array}$ & $\begin{array}{l}\text { Couple, under } \\
60, \text { no } \\
\text { child(ren) / } \\
\text { All working } \\
\text { full time }\end{array}$ & $\begin{array}{l}\text { Lone parent } \\
\text { with } \\
\text { dependent } \\
\text { child(ren) / } \\
\text { Not working } \\
\text { full time }\end{array}$ \\
\hline Mon & 177.44 & 87.44 & - & 22.75 & 67.41 & 71.64 & 57.08 \\
\hline Tue & 151.72 & 90.67 & - & 16.03 & 155.1 & 93.69 & 112.22 \\
\hline Wed & 146.5 & 20.3 & - & 43.82 & 213.81 & 82.79 & 205.98 \\
\hline Thurs & 212.99 & 81.43 & - & 42.71 & 149.6 & 10.23 & 169.06 \\
\hline Fri & 247.29 & 14.98 & - & 56.85 & 263.06 & 68.05 & 95.28 \\
\hline Sat & 109.99 & 85.59 & - & 26.5 & 138.45 & 88.11 & 81.05 \\
\hline Sun & 129.74 & 91.32 & - & 49.33 & 183.36 & 59.04 & 42.17 \\
\hline
\end{tabular}




\section{APPENDIX C}

Appendix C: Post hoc multiple comparison test results (ii) - comparison of daily occupancy profiles across household groups, using 'Couple, over 60, no child(ren) / No one working full time' as control. An observed difference of more than the critical value set by the test (90.52), at 0.05 significance level, indicates that the profile of that group for that day is significantly different from the control household group for the same day.

Observed difference against control group (Critical difference: 90.52)

\begin{tabular}{|c|c|c|c|c|c|c|c|}
\hline \multicolumn{8}{|c|}{ State: 'at home and sleeping' } \\
\hline & $\begin{array}{l}\text { One person, } \\
\text { over } 60 \text { / } \\
\text { Not working } \\
\text { full time }\end{array}$ & $\begin{array}{l}\text { One person, } \\
\text { under } 60 \text { / } \\
\text { Working full } \\
\text { time }\end{array}$ & $\begin{array}{l}\text { Couple with } \\
\text { dependent } \\
\text { child(ren) / } \\
\text { All working full } \\
\text { time }\end{array}$ & $\begin{array}{l}\text { Couple with } \\
\text { dependent } \\
\text { child(ren) / } \\
\text { At least one } \\
\text { person working } \\
\text { full time }\end{array}$ & $\begin{array}{l}\text { Couple, over } \\
60, \text { no } \\
\text { child(ren) / } \\
\text { No one } \\
\text { working full } \\
\text { time }\end{array}$ & $\begin{array}{l}\text { Couple, under } \\
60, \text { no } \\
\text { child(ren) / } \\
\text { All working } \\
\text { full time }\end{array}$ & $\begin{array}{l}\text { Lone parent } \\
\text { with } \\
\text { dependent } \\
\text { child(ren)/ } \\
\text { Not working } \\
\text { full time } \\
\end{array}$ \\
\hline Mon & 72.26 & 76.9 & 6.39 & 91.39 & - & 73.64 & 57.18 \\
\hline Tue & 6.42 & 5.09 & 44.63 & 102.36 & - & 51.3 & 77.97 \\
\hline Wed & 123.36 & 33.32 & 91.72 & 36.8 & - & 39.82 & 55.49 \\
\hline Thurs & 7.14 & 31.36 & 47.64 & 66.94 & - & 37.49 & 19.19 \\
\hline Fri & 59.06 & 46.71 & 55.42 & 8.23 & - & 6.51 & 46.79 \\
\hline Sat & 58.03 & 50.07 & 112.44 & 50.44 & - & 56.42 & 61.29 \\
\hline Sun & 48.41 & 50.63 & 53.62 & 73.78 & - & 62.56 & 14.04 \\
\hline \multicolumn{8}{|c|}{ State: 'at home and not sleeping' } \\
\hline & $\begin{array}{l}\text { One person, } \\
\text { over } 60 \text { / } \\
\text { Not working } \\
\text { full time }\end{array}$ & $\begin{array}{l}\text { One person, } \\
\text { under } 60 \text { / } \\
\text { Working full } \\
\text { time }\end{array}$ & $\begin{array}{l}\text { Couple with } \\
\text { dependent } \\
\text { child(ren) / } \\
\text { All working full } \\
\text { time }\end{array}$ & $\begin{array}{l}\text { Couple with } \\
\text { dependent } \\
\text { child(ren) / } \\
\text { At least one } \\
\text { person working } \\
\text { full time }\end{array}$ & $\begin{array}{l}\text { Couple, over } \\
60, \text { no } \\
\text { child(ren) / } \\
\text { No one } \\
\text { working full } \\
\text { time }\end{array}$ & $\begin{array}{l}\text { Couple, under } \\
60, \text { no } \\
\text { child(ren) / } \\
\text { All working } \\
\text { full time }\end{array}$ & $\begin{array}{l}\text { Lone parent } \\
\text { with } \\
\text { dependent } \\
\text { child(ren)/ } \\
\text { Not working } \\
\text { full time } \\
\end{array}$ \\
\hline Mon & 49.42 & 169.24 & 128.53 & 124.13 & - & 164.87 & 115.94 \\
\hline Tue & 11.48 & 246.7 & 196.42 & 185.35 & - & 188.87 & 109.58 \\
\hline Wed & 16.51 & 132.56 & 201.72 & 165.73 & - & 218.7 & 73.09 \\
\hline Thurs & 41.05 & 205.81 & 147.06 & 163.44 & - & 169.07 & 114.76 \\
\hline$F r i$ & 9.85 & 210.26 & 195.00 & 199.99 & - & 242.7 & 144.39 \\
\hline Sat & 30.38 & 189.28 & 192.31 & 167.98 & - & 255.62 & 239.95 \\
\hline Sun & 34.92 & 194.03 & 178.26 & 168.14 & - & 202.19 & 135.14 \\
\hline \multicolumn{8}{|c|}{ State: 'away from home' } \\
\hline & $\begin{array}{l}\text { One person, } \\
\text { over } 60 \text { / } \\
\text { Not working } \\
\text { full time }\end{array}$ & $\begin{array}{l}\text { One person, } \\
\text { under } 60 \text { / } \\
\text { Working full } \\
\text { time }\end{array}$ & $\begin{array}{l}\text { Couple with } \\
\text { dependent } \\
\text { child(ren) / } \\
\text { All working full } \\
\text { time }\end{array}$ & $\begin{array}{l}\text { Couple with } \\
\text { dependent } \\
\text { child(ren) / } \\
\text { At least one } \\
\text { person working } \\
\text { full time }\end{array}$ & $\begin{array}{l}\text { Couple, over } \\
60, \text { no } \\
\text { child(ren) / } \\
\text { No one } \\
\text { working full } \\
\text { time }\end{array}$ & $\begin{array}{l}\text { Couple, under } \\
60, \text { no } \\
\text { child(ren) / } \\
\text { All working } \\
\text { full time }\end{array}$ & $\begin{array}{l}\text { Lone parent } \\
\text { with } \\
\text { dependent } \\
\text { child(ren)/ } \\
\text { Not working } \\
\text { full time } \\
\end{array}$ \\
\hline Mon & 109.99 & 184.9 & 67.45 & 44.7 & & 139.1 & 124.53 \\
\hline Tue & 3.38 & 245.78 & 155.1 & 171.14 & - & 248.79 & 42.88 \\
\hline Wed & 67.31 & 234.11 & 213.82 & 169.99 & - & 296.6 & 7.83 \\
\hline Thurs & 63.39 & 231.03 & 149.6 & 106.89 & - & 159.83 & 19.45 \\
\hline Fri & 15.78 & 278.05 & 263.06 & 206.21 & - & 331.11 & 167.8 \\
\hline Sat & 28.46 & 224.04 & 138.45 & 164.95 & - & 226.56 & 219.5 \\
\hline Sun & 53.62 & 274.68 & 183.36 & 134.03 & - & 242.4 & 141.19 \\
\hline
\end{tabular}

